OPEN ACCESS

Edited by:

Mark S. Cragg

University of Southampton,

United Kingdom

Reviewed by:

Kun Ping Lu,

Harvard Medical School,

United States

Khiyam Hussain,

University of Southampton,

United Kingdom

*Correspondence: William A. McEwan

wm305@cam.ac.uk

Specialty section: This article was submitted to

Molecular Innate Immunity,

a section of the journal

Frontiers in Immunology

Received: 27 December 2018 Accepted: 07 May 2019

Published: 31 May 2019

Citation:

Katsinelos T, Tuck BJ, Mukadam AS and McEwan WA (2019) The Role of

Antibodies and Their Receptors in Protection Against Ordered Protein Assembly in Neurodegeneration.

Front. Immunol. 10:1139.

doi: 10.3389/fimmu.2019.01139

\section{The Role of Antibodies and Their Receptors in Protection Against Ordered Protein Assembly in Neurodegeneration}

\author{
Taxiarchis Katsinelos, Benjamin J. Tuck, Aamir S. Mukadam and William A. McEwan*
}

Department of Clinical Neurosciences, UK Dementia Research Institute at the University of Cambridge, Cambridge, United Kingdom

Ordered assemblies of proteins are found in the postmortem brains of sufferers of several neurodegenerative diseases. The cytoplasmic microtubule associated protein tau and alpha-synuclein $(\alpha S)$ are found in an assembled state in Alzheimer's disease and Parkinson's disease, respectively. An accumulating body of evidence suggests a "prion-like" mechanism of spread of these assemblies through the diseased brain. Under this hypothesis, assembled variants of these proteins promote the conversion of native proteins to the assembled state. This likely inflicts pathology on cells of the brain through a toxic gain-of-function mechanism. Experiments in animal models of tau and $\alpha \mathrm{S}$ pathology have demonstrated that the passive transfer of anti-tau or anti- $\alpha \mathrm{S}$ antibodies induces a reduction in the levels of assembled proteins. This is further accompanied by improvements in neurological function and preservation of brain volume. Immunotherapy is therefore considered one of the brightest hopes as a therapeutic avenue in an area currently without disease-modifying therapy. Following a series of disappointing clinical trials targeting beta-amyloid, a peptide that accumulates in the extracellular spaces of the AD brain, attention is turning to active and passive immunotherapies that target tau and $\alpha \mathrm{S}$. However, there are several remaining uncertainties concerning the mechanism by which antibodies afford protection against self-propagating protein conformations. This review will discuss current understanding of how antibodies and their receptors can be brought to bear on proteins involved in neurodegeneration. Parallels will be made to antibody-mediated protection against classical viral infections. Common mechanisms that may contribute to protection against self-propagating protein conformations include blocking the entry of protein "seeds" to cells, clearance of immune complexes by microglia, and the intracellular protein degradation pathway initiated by cytoplasmic antibodies via the Fc receptor TRIM21. As with anti-viral immunity, protective mechanisms may be accompanied by the activation of immune signaling pathways and we will discuss the suitability of such activation in the neurological setting.

Keywords: prion-like proteins, neurodegeneration, tau (MAPT), Fc receptor, microglia, antibody immunity, alphasynuclein, beta-amyloid 


\section{PROTEOPATHY IN NEURODEGENERATION}

Following the death of his patient, Auguste Deter, in 1906, Alois Alzheimer described the presence of abundant extracellular plaques and intracellular neurofibrillary tangles in her brain (1). These lesions were subsequently shown to be widely distributed in the brains of sufferers of the disease that went on to take Alzheimer's name. The plaques and tangles are now known to comprise of assemblies of the proteins amyloid- $\beta$ (A $\beta)$ and hyperphosphorylated microtubule associated tau, respectively. Alzheimer's disease (AD) is the most common of a heterogeneous family of age-related neurodegenerative disorders characterized by the deposition of specific protein assemblies in the brain. This includes progressive supranuclear palsy (PSP), corticobasal degeneration and Pick's disease, where tau deposition is observed; dementia with Lewy bodies and Parkinson's disease (PD) where cytoplasmic protein $\alpha$-synuclein $(\alpha S)$ deposits are observed; sporadic Creutzfeldt-Jakob disease, where the membrane-anchored prion protein, $\operatorname{Pr} \mathrm{P}$, is deposited and, finally, amyotrophic lateral sclerosis where TAR DNA binding protein 43 (TDP-43) is implicated. The common characteristics of the protein assemblies among these pathological conditions is that they exhibit an ordered fibrillar structure, known as amyloid, as well as a range of smaller assemblies generally referred to as oligomers. Together, the age-related neurodegenerative diseases are one of the most pressing biomedical and societal problems. Dementia, of which $\mathrm{AD}$ is the most common cause, affects around 50 million people worldwide and numbers are expected to double before the middle of the 21st century. Critically, there are currently no treatments that slow or prevent the progression of any of the age-related neurodegenerative diseases.

Findings over the past few decades place protein aggregation as a central mediator of pathology. Human genetics has revealed numerous mutations in the genes that encode the aggregating proteins themselves. A suite of more than 40 mutations in tau cause inherited dementias, with evidence of tau fibrils in brain tissue (2). Mutations in $\alpha \mathrm{S}$ lead to inherited forms of Parkinson's disease and, in certain cases, an acceleration of in vitro $\alpha \mathrm{S}$ fibrilization $(3,4)$. Mutations in the gene that encodes amyloid precursor protein (APP), the protein from which the $A \beta$ peptide is derived, lead to increased levels of the aggregation-prone $A \beta_{42}$ and familial $A D$ (5). Other mutations in genes responsible for processing these proteins, such as the proteases responsible for the generation of $A \beta$, or in clearing misfolded proteins species, such as the AAA ATPase p97/VCP, can also lead to inherited variants of neurodegenerative diseases $(6,7)$. Collectively, these genetic associations suggest that the accumulation of protein aggregates causes neurodegeneration. For $\mathrm{AD}$, the prevailing framework of disease progression is the amyloid cascade hypothesis $(8,9)$. Under this hypothesis, the accumulation of $\mathrm{A} \beta$ plaques drives pathological consequences that include the formation of tau fibrils and neuronal cell death. Therapeutic approaches in $\mathrm{AD}$ have therefore focused on preventing the production of $A \beta$, or promoting its clearance. A series of disappointing, high profile clinical trials have led to the critical reappraisal and amendment of the amyloid cascade hypothesis, or to propose earlier intervention, since the downstream events unleashed by $A \beta$ accumulation may be irreversible $(5,10)$. Therapeutic approaches that target tau in $\mathrm{AD}$ are therefore considered promising routes for future intervention. Of the 20 therapeutic strategies that target tau that have reached clinical, nine are based on passive transfer or eliciting of antibodies (11). A further two therapies that target $\alpha \mathrm{S}$ have also reached the clinic. Immunotherapy therefore represents one of the brightest hopes for modifying disease progression in age-related dementias.

\section{PROTEIN ASSEMBLIES AS PROPAGATING ENDO-PATHOGENS}

The occurrence of protein deposits was long considered a cell-autonomous feature of neurodegeneration. Over the past few decades, this view has been challenged by a body of research demonstrating that pathological protein conformations can provoke native protein to adopt the assembled form. By consuming pools of native cellular proteins, the assembled variants can sustain their propagation through time and space within the affected brain. The prototypic example of this behavior is the prion protein, $\mathrm{PrP}$, wherein the normal cellular variant, $\mathrm{PrP}^{\mathrm{C}}$, is converted to a pathogenic variant, $\operatorname{PrP}^{\mathrm{Sc}}$. Most cases of prion disease are sporadic or inherited though, in rare cases, disease can be acquired from the environment by eating diseased meat or human brain as occurred in now-abandoned tribal rituals. The model of templated protein aggregation was proposed as a common mechanism in neurodegeneration when it was shown that $A \beta$ could be induced to aggregate in mice expressing APP $(12,13)$. As an extracellular peptide, the seeded aggregation of $A \beta$ likely relies on direct contact between introduced seed and the available pools of peptide. For other proteins such as tau and $\alpha \mathrm{S}$, which are expressed in the cytoplasm, pools of native protein are maintained within cell-limiting membranes, thereby limiting contact between seed and substrate. Seeded aggregation of cytoplasmic proteins was nonetheless demonstrated when AD brain homogenate was found to induce tau pathology in mice expressing wild-type human tau (14). In cultured cell systems, protein misfolding could be transmitted from the extracellular environment to cytoplasmic tau pools (15). Similar properties have been demonstrated for $\alpha$ S, TDP-43, and huntingtin, the protein whose expanded polyglutamine tract is implicated in Huntington's disease (16-19). Thus, although diverse in their clinical manifestations, it is possible that agerelated neurodegenerative diseases share a common "prionlike" mechanism of dissemination though affected brains (20) (Figure 1).

Understanding the molecular mechanisms governing the transfer of pathology between cells is central to any mechanismbased intervention. For immunotherapy against tau and $\alpha \mathrm{S}$, the issue is key as it determines which pool of protein should preferentially be targeted. In vitro studies in neurons demonstrate that tau misfolding can be transferred across synapses $(21,22)$. This is consistent with animal work, which suggests that tau pathology is preferentially transmitted between 


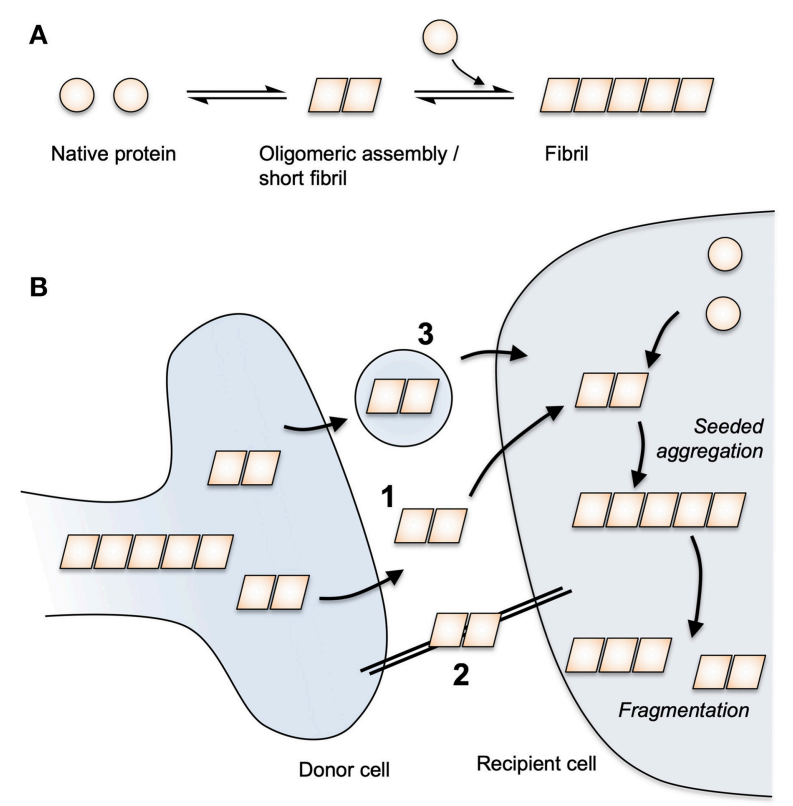

FIGURE 1 | Protein aggregation and prion-like spread. (A) Native protein undergoes a spontaneous conversion to an assembled state. Assemblies above a critical size are able to extend via the addition of native protein monomers to form a fibril. (B) Assembled protein species are able to transmit between cells via routes that may include (1) free protein release and uptake, (2) tunneling nanotubes and (3) extracellular vesicles. Once taken up to the cytoplasm of a neighbouring cell, seeded aggregation occurs through the templated addition of native protein. By fragmenting, fibrils can exponentially amplify in number

connected regions of the brain (23-25). Furthermore, imaging of human brains using positron emission tomography (PET) tracers reveals that network connectivity is correlated with tau pathology, consistent with transfer of tau misfolding along synaptically connected pathways in the brain (26). Extracellular naked protein assemblies transiting between neurons thus represent an attractive target for immunotherapy as they are physically accessible to antibodies. However, other mechanisms of intercellular transfer have been described. For instance, exosomes and extracellular vesicles can contain tau and transmit pathology $(27,28)$ and tunneling nanotubes, actin-containing structures that bridge cells, can transmit pathology in culture $(29,30)$. There also remains discussion around the contribution of prion-like spread vs. cell-autonomous aggregation (31). Assuming that protein seeds are not obtained from the environment, then cell-autonomous aggregation must, at least, be responsible for the generation of the original seed. In this way, the extent to which pathology is governed by cell autonomous vs. prion-like mechanisms, and the route of such spread, define the limits of what any given therapeutic approach can achieve.

\section{ANTIBODIES IN THE BRAIN}

IgG levels are maintained in human serum at around $10 \mathrm{mg} / \mathrm{ml}$. The brain is isolated from serum by the blood-brain barrier (BBB), which is impermeable to large macromolecules including
IgG (32). The brain, instead, is bathed in cerebrospinal fluid (CSF), which is produced following the filtration of blood and transport of ions across the choroid plexus. The resulting concentration of IgG in CSF is around 500- to 1,000-fold lower than in serum. At face value, this low concentration of antibody in the brain makes CNS antigens unattractive as targets for passive immunotherapy, which is normally administered to the periphery. This is compounded by a poor understanding of the mechanisms by which steady state levels of antibody are maintained. CSF flows around the brain, before exiting the CNS along spinal and cranial nerves and via drainage to the lymphatic system $(33,34)$. Intrathecally administered IgG is rapidly cleared from the brain, largely through this bulk flow and with a possible contribution of selective transport out of the brain. The neonatal Fc receptor, FcRn, is expressed in abundance at the BBB (35). Given FcRn's role in transcytosis of antibodies across the placenta, it has been suggested that FcRn may perform reverse transcytosis to help maintain the low IgG environment of the CNS. There is some evidence that antibody clearance from the brain is mediated in part by the antibody Fc domain $(36,37)$, and export of an anti-A $\beta$ monoclonal antibody was reduced in an FcRn-deficient mouse (38). However, the brain concentration of peripherally administered IgG was not significantly different between wild-type mice and mice lacking FcRn (39). This speaks to a need for further investigation of how antibody levels in the CNS are maintained, with a particular requirement to understand the rate of transit across the BBB (Figure 2). Under a model where antibodies are maintained at static, low levels in the CNS, there is little scope for achieving meaningful binding occupancy to intracerebral antigens. However, if there exists a rapid cycling of antibodies in and out of the brain, total exposure of antibodies to antigen will, over time, be substantially greater. Evidence in support of a high flux dynamic equilibrium comes from experiments that measured the rate of clearance of intrathecally administered IgG, which demonstrated a half-life of $<1 \mathrm{~h}$ in a primate model (40). This compares to a half-life of around 3 weeks in the periphery. Thus, peripherally produced or administered antibodies, particularly if they have high affinity for their antigens, may gain sufficient exposure to meaningfully engage intracerebral antigens.

The assertion that antibodies can bind antigens in the brain and exert biological effects is supported by several strands of clinical evidence. For instance, there is a growing set of neuroimmune diseases associated with auto-antibodies that bind to neuronal targets $(41,42)$. Antibodies against the membraneassociated protein amphiphysin are causally linked to the rare progressive disease stiff-person syndrome (43). Antibodies against antigens such as Zic4 and Yo/PCA1 are associated with cerebellar ataxia and antibodies against N-methyl-D-aspartate receptor (NMDAR) are commonly associated with encephalitis (44). From animal and clinical studies it has been shown that peripherally administered antibodies that target $\mathrm{A} \beta$ can engage their targets and induce reductions in brain amyloid load (45-49). Though an unwanted side effect, the ability of passive immunotherapy against $\mathrm{A} \beta$ to induce lesions (amyloidrelated imaging abnormalities or ARIAs, discussed further below), stands as further testament to ability of antibodies 


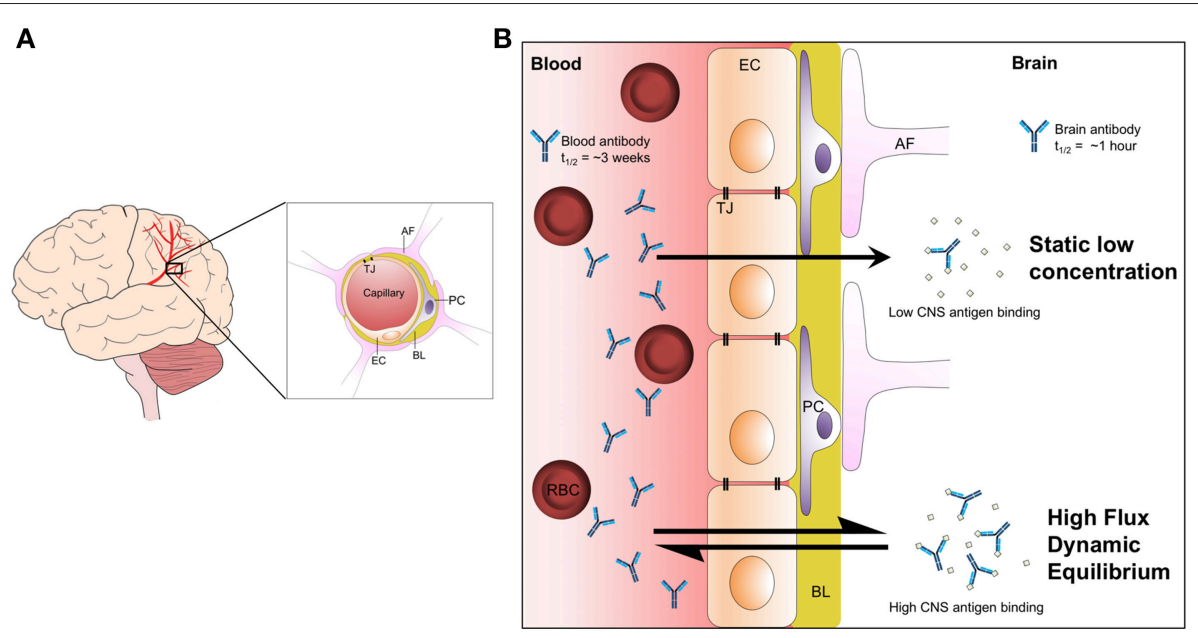

FIGURE 2 | The maintenance of brain antibody levels. (A) Graphical representation of blood vessels in the brain and the cellular structure of the BBB. Endothelial cells in blood vessels interact via tight junctions, restricting the passage of solutes to the CNS. Pericytes bind to the basal lamina and provide structural support to the barrier. Astrocytic foot processes extend from the interstitial spaces to interact with the basal lamina and surrounding cells. (B) Two models of antibody cycling into the CNS. Under a model of static, low concentration in the CNS, antigen binding is highly restricted. However, a model where antibodies rapidly cycle in and out of the brain permits continuous bathing of brain antigens in dilute antibody solution. Over time, this model allows much higher levels of antigen binding. Evidence in support of such a model includes the observation that antibody half-life in the brain is $<1 \mathrm{~h}$, compared to around 3 weeks in serum. AF, astrocyte foot; BL, basal lamina; EC, endothelial cell; PC, pericyte; RBC, red blood cell; TJ, tight junction.

to engage targets in the brain parenchyma. Together, these clinical observations stand as strong evidence that antibodies in circulation can penetrate the brain and engage their targets at a level sufficient to exert biologically relevant effects.

\section{FC RECEPTORS AND THEIR EXPRESSION IN THE BRAIN}

Fc $\gamma$ Rs are expressed on the surface of a wide range of immune effector cell types and bind to the Fc region of IgG. The canonical Fc $\gamma$ Rs are divided into those that activate immune signaling upon binding to antibody (in humans these are Fc $\gamma$ RI, Fc $\gamma$ RIIa, Fc $\gamma$ RIIc, and Fc $\gamma$ RIIIa), one that exerts inhibitory function (Fc $\gamma$ RIIb), and one neutral glycosylphosphatidylinositol (GPI)linked receptor, Fc $\gamma$ RIIIa, which lacks cytoplasmic domains and is highly expressed on neutrophils (Table 1). There are four subclasses of IgG (IgG1, IgG2, IgG3, and IgG4) with varying affinity for the different receptors. The high-affinity interactions are between Fc $\gamma$ RI and all IgG subclasses except IgG2, and between Fc $\gamma$ RIIIa and IgG3 (50). The high-affinity interactions permit binding to free IgG molecules, yet are not of such high affinity that they preclude responses to IgG-labeled multivalent complexes (50). There is a widespread, but erroneous, belief that IgG4 is a neutral subclass of IgG. In fact, it binds all Fc $\gamma$ Rs, albeit with slightly lower affinity than $\operatorname{IgG1}(50,51)$. However, IgG4 does not fix complement and can inhibit IgG1-mediated complement fixation $(52,53)$. Uniquely among the human antibody subclasses, IgG4 undergoes arm exchange, resulting in chimeric, bispecific antibodies (54). In mice, the FcR system is broadly similar, with activating Fc $\gamma$ Rs (Fc $\gamma$ RI, Fc $\gamma$ RIII, and $\mathrm{Fc} \gamma \mathrm{RIV}$ ) and one with inhibitory activity (Fc $\gamma \mathrm{RII}$ ) (Table 2). Like humans, there are four IgG subclasses, (IgG1, IgG2a, IgG2b, and IgG3) though the nomenclature differs between the species: for instance, IgG2a is most similar in its effector functions to human IgG1. The atypical Fc receptor TRIM21 is broadly expressed in the cytoplasm and possesses ubiquitin ligase activity. It can bind all classes of $\operatorname{IgG}(55)$ as well as $\operatorname{IgA}$ and $\operatorname{IgM}(56,57)$. Following detection of intracellular immune complexes, TRIM21 stimulates a co-ordinated series of ubiquitination steps culminating in the degradation of immune complexes at the proteasome and an antiviral transcriptional response $(56,58-60)$.

The major site of Fc receptor expression in the brain is on the surface of microglia, the resident phagocytic immune effector cells of the CNS. In humans this includes the cell surface receptors Fc $\gamma$ RI, Fc $\gamma$ RIIa, Fc $\gamma$ RIIb, and Fc $\gamma$ RIIIa (62). There are reports of $\mathrm{Fc} \gamma \mathrm{Rs}$ on other cell types in the mouse brain, including on neurons $(62,63)$. However, other studies that sought evidence of Fc $\gamma \mathrm{R}$ expression at the transcript and protein level suggest that expression is minimal or absent in cells other than microglia $(64,65)$. The discrepancies between these findings may lie in the region of the brain analyzed as staining has been reported to be specific to regional neuron populations (66) or may reflect ex vivo vs. in vivo conditions. Outside the brain, Fc $\gamma$ RI expression has been detected on sensory and motor neurons (67-69). TRIM21 is universally expressed and we have confirmed its expression in mouse primary neurons and human neuroblastoma cells (70). The neurodegenerating brain is an inflamed state, with widespread microglial activation and production of inflammatory cytokines including TNF, IL-6, and IL-1 $\beta$ (71, 72). Levels of TRIM21 and cell surface Fc $\gamma$ Rs are both increased following immune activation $(58,73)$. This is pertinent to the development of immunotherapeutics, as the degenerating brain may exhibit an 
TABLE 1 | Human Fc receptors.

\begin{tabular}{|c|c|c|c|c|c|}
\hline Name & Activity & $\begin{array}{l}\text { High affinity } \\
\text { ligands }\end{array}$ & Low affinity ligands & Peripheral expression & Brain expression \\
\hline $\mathrm{Fc} \gamma \mathrm{RI}$ & Activatory & $\lg \mathrm{g} 1, \lg \mathrm{G} 3, \lg \mathrm{G} 4$ & & $\mathrm{M} \phi, \mathrm{DC}$ & $M G$ \\
\hline Fc $\gamma$ Rlla & Activatory & & All lgG subclasses & Mф, DC, Neutrophil, Basophil, MC, Eo, PI & MG \\
\hline$F_{c} \gamma R \| l b$ & Inhibitory & & All lgG subclasses & B cells, Basophil, DC, Mф & $M G$ \\
\hline Fc $\gamma R$ Rllc & Activatory & & All lgG subclasses & NK, M $\phi$, Neutrophils & $?$ \\
\hline Fc $\gamma$ RIIIa & Activatory & $\operatorname{lgG3}$ & $\lg G 1, \lg G 2, \lg G 4$ & $\mathrm{NK}, \mathrm{M \phi}$ & MG \\
\hline$F_{c} \gamma R \| l \mid b$ & Neutral & & $\operatorname{lgG} 1, \lg G 3$ & Neutrophils, Basophils & $?$ \\
\hline FcRn & $\begin{array}{l}\text { Transcytosis, } \\
\text { recycling }\end{array}$ & All lgG subclasses & & Mф, DC, Neutrophil & BBB endothelium \\
\hline TRIM21 & Activatory/degradation & All lgG subclasses & $\lg A, \lg M$ & Universal, high in $\mathrm{M} \phi, \mathrm{DC}, \mathrm{B}$ cell & MG, neurons \\
\hline
\end{tabular}

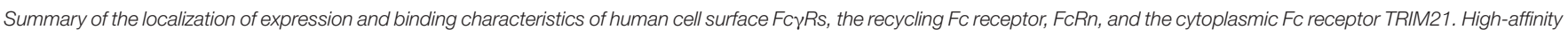

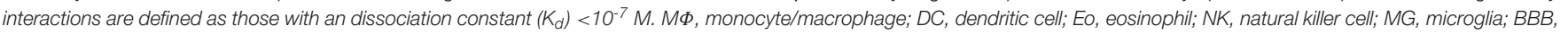
blood-brain barrier. Information for this table adapted from Bruhns and Jönsson (50), Vidarsson et al. (51), and McEwan (61). ? denotes that CNS expression is not defined.

TABLE 2 | Mouse Fc receptors.

\begin{tabular}{|c|c|c|c|c|c|}
\hline Name & Activity & $\begin{array}{l}\text { High affinity } \\
\text { ligands }\end{array}$ & Low affinity ligands & Peripheral expression & Brain expression \\
\hline Fc $\gamma R I$ & Activatory & $\lg G 2 a$ & $\lg G 2 b$ & $\mathrm{M \phi}, \mathrm{DC}$ & $M G$ \\
\hline$F_{c \gamma R \|}$ & Inhibitory & & IgG1, IgG2a, IgG2b, IgE & B cell, M $\phi$, Neutrophil, DC & MG \\
\hline Fc $\gamma R I I I$ & Activatory & & IgG1, IgG2a, IgG2b, IgE & NK, Mф, Neutrophil, DC & $M G$ \\
\hline Fc $\gamma R I V$ & Activatory & $\lg G 2 a, \lg G 2 b$ & $\lg \mathrm{E}$ & M $\phi$, Neutrophil & $M G$ \\
\hline FcRn & Transcytosis, recycling & All lgG subclasses & & Placenta, Mф, Neutrophil, DC & BBB endothelium \\
\hline Trim21 & $\begin{array}{l}\text { Activatory / } \\
\text { degradation }\end{array}$ & All lgG subclasses & $\lg A ?, \lg M ?$ & Universal, high in $M \phi, D C, B$ cell & Neurons, MG \\
\hline
\end{tabular}

Summary of the murine Fc receptors, their binding partners and pattern of expression. As in Table 1, high-affinity interactions are defined as those with an dissociation constant (Kd) $<10^{-7}$ M. MФ, monocyte/macrophage; DC, dendritic cell; Eo, eosinophil; NK, natural killer cell; MG, microglia; BBB, blood-brain barrier; ? denotes possible interaction not yet demonstrated.

exaggerated response to immune complexes. FcR upregulation may enhance the effectiveness of any Fc-mediated clearance mechanism, but has the potential to drive inappropriate immune stimulation. Trials of passively-transferred antibodies against $\mathrm{A} \beta$ have reported ARIAs, which are caused by intracerebral oedemas or microhaemorrhages (74). This represents a clear safety issue for immunotherapies and limits the range of doses available to clinicians. These adverse events are potentially driven by microglial activation following engagement of antibodybound $A \beta$ assemblies by Fc $\gamma$ Rs. Of note, studies on tau, $\alpha S$ and $A \beta$ have reported mechanisms of protection that do not rely on engagement of cell surface Fc $\gamma$ Rs (65, 70, 7579). Current clinical trials are therefore testing monoclonal antibodies with modified effector functions as a means to preserve activity whilst diminishing adverse events $(80,81)$. The nature of these immunotherapies will be discussed further below, before a discussion on their likely mechanisms of action.

\section{CLINICAL IMMUNOTHERAPY}

Several immunotherapies that target proteins implicated in neurodegeneration have entered human clinical trials. They fall into two categories: those that attempt to induce protective immunity in the patient through vaccination (active immunotherapy) or the infusion of monoclonal antibodies (passive immunotherapy). Active immunotherapy has as its benefit the sustained production of antibody from few vaccine doses. However, there remain issues of variable or incomplete protection between individuals and a risk that side effects may be longlasting or irreversible. Passive transfer of monoclonal antibodies permits precise control of dosing and the epitope targeted, avoids stimulating a potentially damaging T-cell response and can be withdrawn in the event of adverse effects. However, the large quantities of recombinantly produced antibody that need to be periodically infused in passive immunotherapy approches come with considerable cost implications.

\section{A $\beta$ Immunotherapies}

The most advanced of the neurodegeneration immunotherapies are those that target $A \beta$ (82), where 11 different approaches have reached clinical trials, seven of which are passively transferred monoclonal antibodies and four of which are active vaccination approaches (82) (Table 3 ). The first of these, AN1792, an active vaccine against full-length $A \beta_{42}$, was halted following the occurrence of meningoencephalitis in $6 \%$ of the study population, all of whom had mild to moderate $\mathrm{AD}$ (83). Post-mortem analysis of two patients who developed 
TABLE 3 | Clinical immunotherapies in neurodegeneration.

\begin{tabular}{|c|c|c|c|c|c|}
\hline Name & Immunotherapy type & Target & Company & $\begin{array}{l}\text { Most advanced } \\
\text { clinical trial ID }\end{array}$ & Phase of trial \\
\hline \multicolumn{6}{|c|}{ IMMUNOTHERAPIES TARGETING $\alpha \mathrm{S}$ and TAU } \\
\hline AADvac1 & Active & Tau 294-305 & Axon Neuroscience & $\begin{array}{l}\text { NCT02579252 (mild } \\
\text { AD) }\end{array}$ & Phase II \\
\hline $\mathrm{ACl}-35$ & Active & Tau pS396, pS404 & AC Immune \& Janssen & $\begin{array}{l}\text { ISRCTN13033912 } \\
\text { (mild to moderate AD) }\end{array}$ & Phase lb \\
\hline BlIB054 & Passive & $\alpha$-synuclein & Biogen, Neurimmune & NCT03318523 (PD) & Phase II \\
\hline BIIB076 & Passive, hulgG1 & Tau & Biogen, Neurimmune & NCT03056729 & Phase I \\
\hline \multirow[t]{2}{*}{ BIIB092 } & Passive, hulgG4 & Tau N-terminus & $\begin{array}{l}\text { Biogen \& Bristol-Myers } \\
\text { Squibb }\end{array}$ & NCT03068468 (PSP) & Phase II \\
\hline & & & & $\begin{array}{l}\text { NCT03352557 (early } \\
\text { AD) }\end{array}$ & Phase II \\
\hline \multirow[t]{2}{*}{$\mathrm{C} 2 \mathrm{~N}-8 \mathrm{E} 12$} & Passive, hulgG4 & Tau 25-30 & $\begin{array}{l}\text { AbbVie \& C2N } \\
\text { Diagnostics }\end{array}$ & NCT02985879 (PSP) & Phase II \\
\hline & & & & $\begin{array}{l}\text { NCT02880956 (early } \\
\text { AD) }\end{array}$ & Phase II \\
\hline PRX002 & Passive, hulgG1 & $\alpha$-synuclein 118-126 & $\begin{array}{l}\text { Hoffmann La Roche, } \\
\text { Prothena }\end{array}$ & $\begin{array}{l}\text { NCT03100149 (early } \\
\text { PD) }\end{array}$ & Phase II \\
\hline RG7345 & Passive & Tau pS422 & Hoffmann La Roche & NCT02281786 & Phase I (discontinued) \\
\hline \multirow[t]{2}{*}{ R07105705 } & Passive, hulgG4 & Tau & $\begin{array}{l}\text { AC Immune SA, } \\
\text { Genentech \& Hoffmann } \\
\text { La Roche }\end{array}$ & $\begin{array}{l}\text { NCT03289143 } \\
\text { (prodromal to mild AD) }\end{array}$ & Phase II \\
\hline & & & & $\begin{array}{l}\text { NCT03828747 } \\
\text { (moderate AD) }\end{array}$ & Phase II \\
\hline LY3303560 & Passive & Tau conformational epitope & Eli Lilly & $\begin{array}{l}\text { NCT03518073 (early } \\
\text { AD) }\end{array}$ & Phase II \\
\hline JNJ-63733657 & Passive & Tau mid-region & Janssen & NCT03375697 & Phase I \\
\hline UCB0107 & Passive & Tau 235-246 & UCB & NCT03464227 & Phase I \\
\hline \multicolumn{6}{|c|}{ SELECTED IMMUNOTHERAPIES TARGETING A $\beta$} \\
\hline \multirow[t]{2}{*}{ Solanezumab } & Passive lgG1 & $\mathrm{A} \beta$ (monomeric) & Eli Lilly & $\begin{array}{l}\text { NCT02008357 (at risk } \\
\text { of AD / mild AD) }\end{array}$ & Phase III \\
\hline & & & & NCT01760005 (fAD) & Phase III \\
\hline \multirow[t]{2}{*}{ Gantenerumab } & Passive lgG1 & A $\beta$ (assembled) & $\begin{array}{l}\text { Chugai } \\
\text { Pharmaceutical, } \\
\text { Hoffmann La Roche }\end{array}$ & NCT01760005 (fAD) & Phase III \\
\hline & & & & $\begin{array}{l}\text { NCT03444870 (early } \\
\text { AD) }\end{array}$ & Phase III \\
\hline AN1792 & Active & $\mathrm{A} \beta 42$ & Pfizer, Janssen & NCT00021723 & Phase II (terminated) \\
\hline Aducanumab & Passive lgG1 & A $\beta$ (assembled) & Biogen, Neurimmune & $\begin{array}{l}\text { NCT02484547 (early } \\
\text { AD) }\end{array}$ & Phase III \\
\hline Bapineuzumab & Passive lgG1 & A $\beta$ (assembled and soluble) & Pfizer, Janssen & NCT00998764 & Phase III (terminated) \\
\hline
\end{tabular}

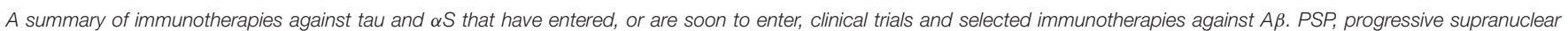
palsy; $A D$, Alzheimer's disease; $P D$, Parkinson's disease; $f A D$, familial Alzheimer's disease.

meningoencephalitis indicated a T-cell mediated response was probably responsible for the inflammatory pathology. A second generation of active immunotherapies aims to target the $\mathrm{N}$ terminus of the $\mathrm{A} \beta$ peptide, thereby avoiding a C-terminal $\mathrm{T}$-cell epitope that may have been responsible for $\mathrm{T}$-cell activation following vaccination with full-length $A \beta$ (83). For the passive immunotherapies against $A \beta$, a reduction in $A \beta$ PET biomarkers has been observed for gantenerumab, aducanumab, and bapineuzumab $(46-48,84)$. Safety issues mainly concern ARIAs, especially in carriers of the APOE4 allele (85). ARIAs are likely due to the antibody decoration of $A \beta$ plaques and the use of antibodies that preferentially bind $A \beta$ monomers over fibrils (e.g., solanezumab) may therefore represent a mechanism to avoid them. Despite the evidence of target engagement, there is no evidence of clinical benefits for any of the drugs that have been tested in Phase III trails, which are powered to 
test efficacy. As the Phase III trials conducted to date have been conducted in patient groups with established AD, their failure suggest earlier treatment may be critical for cognitive benefits. Future trials will test this hypothesis in populations with dominantly inherited dementias, or at risk of developing sporadic $\mathrm{AD}$ based on PET A $\beta$ accumulation, using gantenerumab and solanezumab $(86,87)$. There therefore remains cause for hope in the targeting of $\mathrm{A} \beta$ in $\mathrm{AD}$, but, if it is to be successful, it will likely require early intervention, a pre-requisite of which is predictive diagnostics.

\section{Immunotherapy Against Cytoplasmic Proteins}

Over the past decade, it has been repeatedly shown that active vaccination against tau or $\alpha S$ can alleviate the burden of pathology in the mouse brain (88-94). The mechanism of this immune protection is likely mediated by humoral immunity, as passive transfer of anti-tau antibodies is sufficient to confer a protective effect (95-100). This situation is reminiscent of viral infections, where the passive transfer of antibodies often confers sterile protection against infection $(101,102)$. Encouraged by the reductions in protein pathology, preservation of brain volume and ameliorations of behavioral metrics in mouse studies, clinical trials of tau and $\alpha \mathrm{S}$ immunotherapies have commenced, or are planned (Table 3) $(103,104)$. We here summarize the therapies, and the rationale behind them, using the available pre-clinical and clinical data.

\section{AADVac1}

Following screening of antibodies that inhibited in vitro aggregation of recombinant tau, a monoclonal antibody, DC8E8, was identified with potent inhibitory activity (105). The epitope of this antibody is HXPGGG, a motif present in each of the four repeat domains of full-length tau. Passive transfer of DC8E8 was protective in a transgenic mouse expressing truncated human tau. This data was used to select an epitope for active vaccination (tau 294-305 KDNIKHVPGGGS), conjugated to keyhole limpet hemocyanin $(\mathrm{KLH})$. In transgenic rats expressing truncated human tau, the vaccine was alum-adjuvanted and was found to confer a reduction in total and hyperphosphorylated tau species (106). Following these findings, human trials of the vaccine were commenced. A Phase I trial demonstrated that vaccination successfully induced an anti-tau immune response in 29/30 patients, which was biased toward an IgG1 response $(107,108)$. Phase II trials are underway in mild $\mathrm{AD}$ and primary progressive aphasia patients (109).

\section{ACI-35}

ACI-35 is a 16mer peptide comprising tau residues 393-408 with phosphorylation at S396 and S404 (91). This overlaps with the epitope of PHF1, an antibody widely used to detect pathological tau species (110). In the ACI-35 vaccine, the doubly-phosphorylated tau peptide is delivered in liposomes. Vaccination conferred a reduction in levels of soluble and insoluble tau phosphorylated at S396 in mice transgenic for human P301L tau (91). Protection against other phosphorylation sites of tau were not observed. Levels of insoluble tau were reduced but were not statistically significant by conventional criteria. The vaccine promoted the rescue of a clasping defect in the P301L tau transgenic mice but had no effect in the Rotarod test, a more demanding agility task. From a safety perspective, there was no observed influx of lymphocytes and no induction of astrogliosis. A Phase Ib clinical trial is currently taking place in $\mathrm{AD}$ patients with mild to moderate symptoms.

\section{BIIB076}

BIIB076 is a fully human IgG1, derived from Neurimmune's reverse translational approach, which mines antibody sequences isolated from humans. Little pre-clinical work has been published for BIIB076, though it was found to bind with subnanomolar affinity to human and cynomolgus macaque tau (111). When given to macaques it was found to reduce total and unbound CSF tau at the highest doses. A Phase I trial is under way.

\section{BIIB092}

Induced pluripotent stem cell-derived neurons prepared from familial $\mathrm{AD}$ patients secrete a series of truncated tau products that were termed eTau (112). eTau species consist of the N-terminal region of tau and run between 20 and $35 \mathrm{kDa}$ by SDS-PAGE western blot. When added to primary cortical neurons, eTau caused neuronal hyperactivity and upregulated the expression of $\mathrm{A} \beta$. The authors propose a model wherein secreted tau creates a destructive feed forward loop: $A \beta$ drives tau pathology and secreted tau in turn upregulates A $\beta$. The antibody IPN002 binds the $\mathrm{N}$-terminus of tau and neutralizes the effect of eTau. In vivo, it reduced levels of tau in CSF in P301L tau transgenic mice. IPN007, the humanized IgG4 version of the antibody, now renamed BIIB092, is being evaluated in Phase II trials in PSP and early $\mathrm{AD}$ patient populations.

\section{C2N-8E12}

C2N-8E12 is a humanized IgG4 version of the antibody HJ8.5 that binds with picomolar affinity to the $\mathrm{N}$-terminal region of tau at residues 25-30 (95). In a seeding assay in human embryonic kidney cells (113), HJ8.5 exerted potent protection against tau seeds isolated from aged mice expressing human P301S tau (95). When chronically perfused into the ventricles, or delivered intraperitoneally to the same mouse model, HJ8.5 substantially reduced the extent of staining with antibodies specific for pathological tau and improved cognition $(95,96)$. Two Phase II clinical trials of C2N-8E12 are currently in progress in PSP and early AD cohorts.

\section{RG7345}

RG7345 is a humanized rabbit monoclonal that targets a C-terminal epitope of tau phosphorylated at S422 (100). The antibody was found to specifically enter neurons that contained hyperphosphorylated tau, suggestive of a targetdependent uptake mechanism. When injected to the periphery of TauPS2APP mice, which express human P301L tau and mutant forms of APP and PSEN2, the antibody reduced levels of tau phosphorylated at S422. The drug entered a Phase I clinical trial that was completed in 2015. However, no results have been 
posted for the trial and Roche discontinued development for unknown reasons.

\section{R07105705}

Genentech and AC Immune published work demonstrating that a mouse IgG2b antibody that targets tau phosphorylated at S409 reduced pathological tau staining in P301L tau transgenic mice (65). Mutation of the D265A and N297G (DANG) residues of the antibody, which prevents binding of cell surface Fc $\gamma$ Rs but not to murine complement (114), did not substantially reduce protection but prevented release of inflammatory cytokines by microglia (65). This work likely informed the selection of the IgG4 backbone for RO7105705, which has reduced capacity to engage microglia when compared to other subclasses (115). The precise epitope of RO7105705 has not been disclosed though it was reported to target the N-terminus (116). Two Phase II trials in prodromal to mild $\mathrm{AD}$ and moderate $\mathrm{AD}$ cohorts are in progress.

\section{JNJ-63733657 and UCB0107}

Based on the rationale that antibodies targeting the termini of tau may ineffectively bind proteolytically-digested tau assemblies, Janssen and UCB have selected antibodies that target the middomain of tau. The antibodies both reportedly block seeded aggregation of tau in cell-based seeding assays (117). These antibodies both recently entered Phase I clinical trials.

\section{LY3303560}

Eli Lilly have humanized a well-characterized conformationspecific antibody, MC-1 (118), which binds a discontinuous epitope of tau comprised of the N-terminal EFE motif (residues 7-9) and the core region (residues 313-322). From cryoelectron microscopy structures, the EFE motif is hypothesized to interact with the core structure in the $\mathrm{AD}$ paired-helical and straight filaments (119). Accordingly, LY3303560 displays a preference for binding aggregated over monomeric tau (120). Little preclinical data have been published and the antibody subclass has not been disclosed. A Phase II clinical trial is currently under way in sufferers of early symptomatic AD.

\section{PRX002}

PRX002 is being developed by Roche and Prothena as an $\alpha \mathrm{S}$ targeting immunotherapy. The mouse monoclonal, 9E4, from which PRX002 derives, belongs to the IgG1 subclass (121). 9E4 targets a C-terminal epitope of $\alpha \mathrm{S}$ (residues 118-126), with a preference of monomeric over assembled versions of $\alpha \mathrm{S}$ (122). When repetitively delivered intraperitoneally to a mouse model that over-expresses wildtype human $\alpha \mathrm{S}$, 9E4 protected against neuronal cell loss and improved behavioral parameters including Rotarod (121). Levels of a C-terminal fragment of $\alpha \mathrm{S}$, and higherorder assemblies of $\alpha S$, were reduced by passive vaccination. 9E4 was found to accumulate in neurons and co-localize with $\alpha S$ and with lysosomal (cathepsin D) and autophagosomal (LC3) markers. Consistent with induction of $\alpha \mathrm{S}$ degradation via autophagy as 9E4's mechanism of action, the intensity of LC3 staining was increased following 9E4 treatment, and clearance of $\alpha \mathrm{S}$ by $9 \mathrm{E} 4$ was prevented by inhibition of autophagy in neuronal cultures. Phase I trials reported favorable safety and pharmacokinetics with evidence of target engagement in serum (123). A Phase II trial is currently in progress in early PD patients.

\section{MECHANISMS OF ANTIBODY-MEDIATED PROTECTION}

Numerous mechanisms have been posited for how antibodies may deplete aggregated proteins in the brain. As with protection against viral infection, particular mechanisms likely dominate the activities of individual monoclonal antibodies. The selection of individual monoclonal antibodies for passive immunotherapy, and modulating antibody effector function, is therefore a means by which specific effector functions may be selected. We will here delineate the mechanisms that are likely to operate against protein aggregates and, where possible, relate them to pre-clinical and therapeutic studies.

\section{Peripheral Sink}

The peripheral sink hypothesis posits that antibodies binding to targets in the periphery will shift equilibrium dynamics across the BBB, thereby reducing the concentration of cerebral antigens (124). This provides a mechanism that would enable the depletion of cerebral antigens by administering antibodies that promote clearance in the periphery. If biologically valid, it would enable the problem of antibody penetrance to the brain to be bypassed, as maintaining peripheral pools would be sufficient to promote CNS antigen depletion. The application of the peripheral sink hypothesis has been mostly applied to $\mathrm{A} \beta$, which can be readily detected in both CSF and serum and therefore potentially susceptible to this process. Solanezumab and ponezumab both selectively target monomeric $\mathrm{A} \beta$, and have been proposed to operate via the peripheral sink mechanism $(125,126)$. Consistent with a transfer to periphery, both antibodies, as well as a monomer-binding monoclonal antibody, m266 which was given to mice, increased the serum concentration of $\mathrm{A} \beta(125,127,128)$. However, this may be an effect of prolonging the half-life of $A \beta$ in serum by complexing with antibody, as concentrations of free $A \beta$ were not diminished. In a non-human primate model, the enzymatic degradation of $A \beta$ in the periphery, although efficient, did not reduce CNS A $\beta$ load (129). This experiment implies that degradation of CNS antigens in the periphery is not sufficient to substantially reduce CNS load. However, it must be noted that anti-A $\beta$ IgG may itself alter the rate of efflux of antigen from the brain by promoting export of antibody:antigen complexes and the enzymatic degradation experiment would not capture this effect. Local production of antibodies against proteopathic agents within the brain, or administration of antibodies directly to the CNS, is associated with high levels of protection $(95,130-133)$. This demonstrates that mechanisms that rely on direct CNS exposure to antibodies can dominate protective effects. It is therefore likely that in order to target CNS antigens effectively, the problem of low antibody concentration in the brain must be confronted headon by ensuring sufficient intracerebral target engagement for therapeutic efficacy. 


\section{Neutralization}

It has been known since the 1930s that the incubation of virus particles with antibodies often results in a reduction in infectious titer, a phenomenon termed neutralization (134). Given the mechanistic similarities between viruses and cytoplasmically replicating proteopathies such as tau and $\alpha \mathrm{S}$, there is value in comparing the effects of antibody on both types of pathogen. Neutralization can only effectively be studied in cell-based models, outside a living organism, as the professional immune system confounds observations. We will here extend established definitions of virus neutralization (135) to cytoplasmic seeded protein misfolding as:

the reduction in seeding potency observed following the binding of antibodies to proteinaceous assemblies in cell-based seeding or propagation assays in the absence of complement or cells of the professional immune system.

This definition therefore excludes the effects of microglial clearance and other effector mechanisms that are likely to operate in vivo. The cellular substrate used for examining the effect of antibodies on seeding ability is typically mouse primary neurons, human cell lines, or, more recently, human neurons derived from induced pluripotent stem cells (136, 137). It remains to be determined whether the choice of cellular model influences the extent, and mechanism, of observed neutralization.

Antibodies that exert potent neutralizing responses against viruses in cell based systems frequently exert strong in vivo protection $(135,138,139)$. Indeed, a neutralizing antibody response is considered a surrogate marker of protective immunity in many circumstances. Until recently neutralization was thought to be synonymous with preventing entry of viruses, or, more specifically, their genomes, to the interior of the cell (135). A post-entry mechanism of neutralization that relies on engagement of the intracellular Fc receptor TRIM21 has recently been characterized, and is discussed further below. For entry-blocking antibodies, though the end result is identical (viruses fail to enter the cell), there are numerous mechanisms by which this may be achieved. For example, antibodies may effect a block to entry by preventing engagement of cell surface receptors, agglutinating virus particles or blocking escape from endosomes, each of which ultimately results in a block to virus entry.

In proteopathic seeding experiments, antibodies have been documented to reduce or slow the uptake of tau to cells. Examples of these are the anti-tau monoclonal antibody HJ9.3 (79) and a polyclonal preparation against the tau Cterminus, which slowed the uptake of tau to iPSC-derived neurons (136). Likewise, the anti- $\alpha S$ antibodies Syn211 and Syn303 reduced the uptake of $\alpha \mathrm{S}$ fibrils to mouse hippocampal neurons (78). Together, these findings demonstrate that entry blocking neutralization can operate against protein assemblies (Figure 3A). However, entry-blocking is by no means a universal mechanism, since the antibody HJ8.5, which potently neutralizes seeding (94), fails to block tau uptake to neurons (79).
The N-terminal monoclonal antibody 5A6 (140) and a Cterminal polyclonal, BR134 (141), similarly exert neutralization activity without substantially preventing uptake (70). For these latter two antibodies, neutralization activity relies on intracellular neutralization via TRIM21. Further, without a firm understanding of the mechanisms of seed entry to the cell, it is not clear exactly how antibodies elicit a block to cellular uptake. For $\alpha S$ fibrils, interactions with the putative entry receptor LAG3 facilitate binding and uptake to cells (142). Inhibition of this interaction with anti-LAG3 antibodies C9B7W and 410C9 reduced $\alpha S$ uptake. For both $\alpha S$ and tau, interactions with sulfated proteoglycans promote aggregate uptake (143-145) and inhibition of this interaction is the proposed mechanism for HJ9.3 (79).

By analogy with viruses, it is conceptually possible that antibodies block entry to the cytosol at a post-uptake stage, for instance by blocking endosomal escape, or by promoting endolysosomal degradation. There has been little study on the ability of antibodies to act at a post-uptake, pre-cytosolic entry stage. Implementation of the necessary methods is technically challenging, and, as with approaches for viral infection, particles that have escaped to the cytoplasm must be reliably differentiated from the endosomal population, which is likely to be overwhelmingly greater. Surrogate markers of tau and $\alpha \mathrm{S}$ entry to the cytoplasm, such as Galectin 3-GFP, which binds carbohydrates on disrupted endosomes, have been developed $(146,147)$ and could be usefully applied to the field of antibody neutralization.

For certain non-enveloped viruses, neutralization can occur entirely independently of entry blocking. Antibodies against adenovirus do not prevent entry to the cell but remain associated with viral particles in the cytoplasm. Once in the cell, antibodies are bound by the cytoplasmic, high-affinity Fc receptor TRIM21, which mounts a rapid degradation response against the immune complex (Figure 3A). This substantially reduces viral infectivity and genetic deletion of TRIM21 renders certain antibodies non-neutralizing (56, 60). Mice that lack TRIM21 are highly susceptible to viral infection and, unlike their wild-type counterparts, cannot be fully protected by passive transfer of neutralizing antibodies (148). The distinguishing feature of viruses that are susceptible to TRIM21 is that their capsids are naked (i.e., without lipid bilayer) and lack fusogenic or membrane pore-forming mechanisms that permit the separation of genomic material and antibody-bound antigens during entry. Rather, these TRIM21-sensitive viruses, which include adenoviruses and minor group rhinovirus (149), enter the cell through lysis of the endosome, leaving the antibodybound virus particle exposed $(150,151)$. The uptake of naked protein assemblies and entry to the cytosol though spontaneous or aggregate-induced lysis of vesicles $(146,147)$, is, similarly, a route that allows access of antibodies to the cytoplasm. Indeed, several studies have found that antibodies are taken up with exogenously added tau seed, and that antibodies do not prevent tau uptake to neurons $(70,79,96,136)$. Antibody-coated tau assemblies that escape to the cytoplasm become associated with TRIM21, and are prevented from inducing seeded aggregation by its activity (70). The extent to which intracellular neutralization 


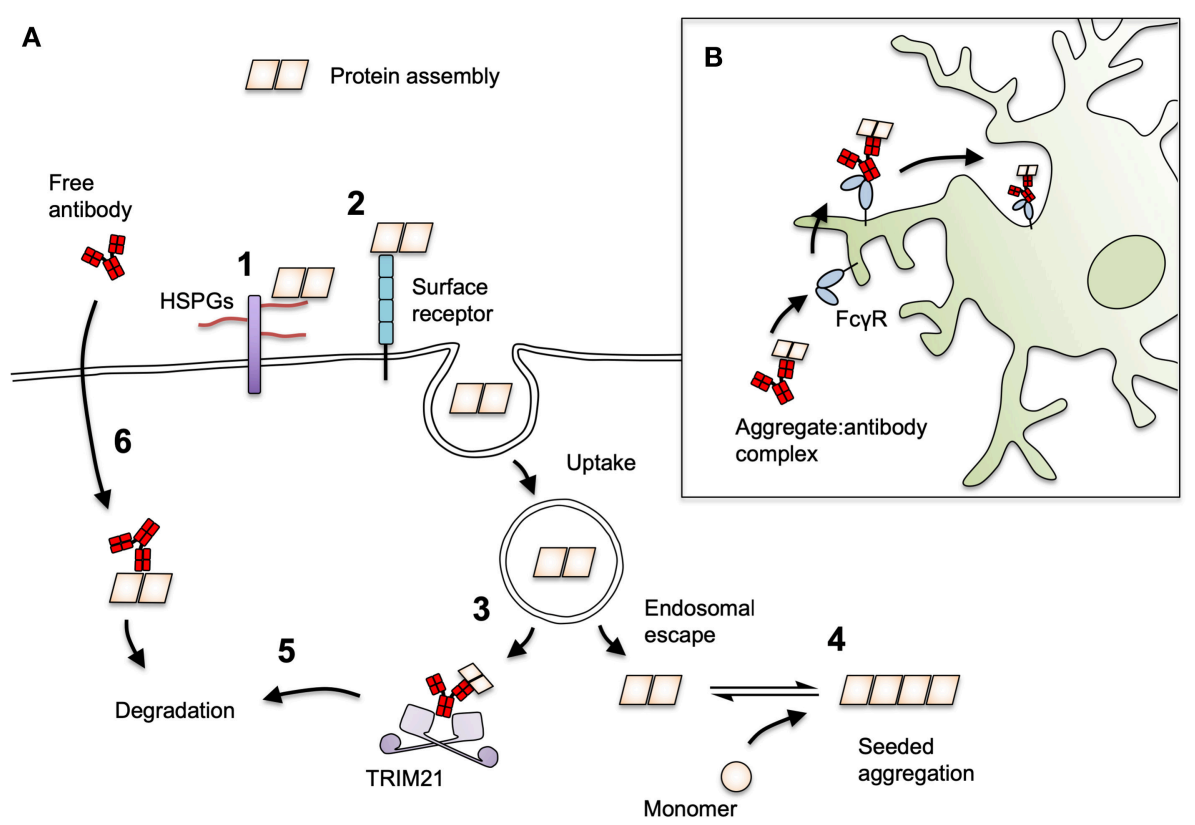

FIGURE 3 | Mechanisms of antibody-mediated protection against prion-like proteins. (A) The process of seeding for tau and $\alpha \mathrm{S}$ may be neutralized by antibodies at several stages. Protein seeds attach to cells via interactions with (1) heparan sulfate proteoglycan (HSPGs) or (2) cell surface receptors such as LAG3 for $\alpha$ S. (3) Seeds must escape vesicular compartments in order to induce seeding, a step that by analogy with viral infection could be inhibited by antibodies. (4) Seeds that escape to the cytoplasm with antibodies attached may be prevented from undergoing seeded aggregation or (5) become targets for proteasomal destruction by the cytoplasmic Fc receptor and ubiquitin ligase, TRIM21. (6) Antibodies may be directly taken up into cells in a target-specific manner and mediate degradation of target proteins in the cytoplasm via TRIM21, or in the lysosome/autophagy pathways. (B) Antibody-decorated aggregates can be ligated by cell surface FcyRs on microglia. This induces their uptake and degradation and may play an important role in overall in vivo protection.

by TRIM21 contributes to the overall in vivo protection afforded by an antibody remains to be determined.

\section{Clearance by Microglia}

Microglia display an ability to take up naked assemblies of tau and $\alpha S$ and induce their degradation $(152,153)$. When in complex with antibodies, cellular uptake and degradation of both tau and $\alpha \mathrm{S}$ is enhanced $(79,154,155)$. This activity is Fc-dependent, as use of $\mathrm{F}(\mathrm{ab}) 2$ fragments, which lack the Fc domain, or Fc $\gamma \mathrm{R}$ blocking antibodies, prevent clearance. This represents a mechanism that can be exploited for the therapeutic clearance of protein deposits (Figure 3B). However, Fc $\gamma$ R-mediated clearance of protein deposits comes with a risk of activating a damaging immune response, as likely occurred during immunotherapy that targeted $\mathrm{A} \beta$ plaques $(74,85)$. Several immunotherapies have selected IgG4 as a scaffold with a rationale that it may minimize damaging pro-inflammatory responses (Table 3). However, as noted above, IgG4 binds Fc $\gamma$ Rs (50) and any reduction in inflammatory induction by IgG4 may owe more to its inability to fix complement $(52,53)$. Nonetheless a side-by-side comparison of an anti-A $\beta$ antibody, MABT, with human IgG1 vs. IgG4 constant regions demonstrated a reduced ability of IgG4 to promote microglial inflammation by $A \beta$ :antibody immune complexes (115). Two recent clinical trials with anti-A $\beta$ IgG4 antibodies with reportedly low ability to engage $F_{c} \gamma$ Rs have commenced $(80,81)$. Uncertainty therefore persists in the selection of antibody isotypes for immunotherapy for maximal therapeutic effect and the extent to which isotype selection influences effector function in the brain. Passive immunotherapies on human IgG1 (BIIB076, PRX002) and IgG4 (BIIB092, C2N-8E12, RO7105705) scaffolds have been selected for clinical trials. Though an imperfect experiment, results of Phase II and III clinical trials, when considered together, will hopefully provide insight regarding the effect of isotype selection on therapeutic outcomes.

As noted above, an anti-pS409 tau antibody that possesses the DANG point mutations that prevent $\mathrm{Fc} \gamma \mathrm{R}$ engagement retains the ability to prevent tau spread and neurotoxicity (65). Thus for antibodies that confer protection via alternative mechanisms, dispensing with $\mathrm{Fc} \gamma \mathrm{R}$ engagement altogether provides a potential safety advantage. Other studies have reported that an antibody against pS404 of the mouse IgG2a isotype, which preferentially binds to activatory Fc $\gamma$ Rs (50), was more potent at clearing tau pathology than a mouse IgG1, which possess enhanced binding to the inhibitory Fc $\gamma$ RII, despite targeting the same epitope with similar affinity (97). This would suggest that activatory microglial engagement, at least for these antibodies, has a net protective effect. Indeed, it has been argued that microglial engagement is both well-tolerated and therapeutically desirable (108). To satisfactorily address these issues, future work should determine the effect of antibody subclass on levels of in vivo protection by isotype switching monoclonal antibodies. 


\section{Intracellular Sequestration or Clearance}

Free antibodies against tau have been found to enter neurons in cell based systems and in passive transfer experiments in mice $(89,99,100,156)$. Antibodies were found in complex with tau in the endolysosomal/macroautophagy pathways, suggesting that degradation is stimulated by antibody uptake. Antibody uptake could be blocked with antibodies against Fc $\gamma$ RII/III in mouse neurons (99). The extent of this phenomenon is not clear, especially given the ambiguity concerning $\mathrm{Fc} \gamma \mathrm{R}$ expression on the surface of neurons. The humanized antibody, MAb86/RG7345, was reported to enter neurons and was found associated with lipid rafts and intracellular or vesicular tau deposits (100). However, clinical trials for this antibody were discontinued for reasons that have not been disclosed. Intracellular sequestration is therefore a mechanism of action that is not explicitly represented in current clinical trials that target tau. It remains to be determined whether the phenomenon of intracellular antibodies involves the wholesale transfer of antibodies to the cytoplasm, or whether vesicles containing tau and antibody meet without cytoplasmic access. In the case of the former, it is expected that intracellular antibodies would be rapidly bound by TRIM21. It is therefore interesting that a monoclonal antibody, cis-113, specific to a soluble cis-tau conformer, was taken up by neurons and found to induce intracellular degradation of tau that was dependent on TRIM21 (157). Thus, both import of antibody in complex with tau seeds and uptake of free antibody by neurons may enable intracellular degradation of pathological protein species via the TRIM21 pathway $(70,157)$. Recent work demonstrates that TRIM21 can rapidly degrade diverse cellular proteins in experimental systems (158). It may therefore be possible to use antibodies and TRIM21 to specifically target disease-relevant protein conformations for degradation in the cytoplasm.

\section{CONCLUDING REMARKS}

The evidence that protein aggregation spreads in a prion-like manner is accumulating and compelling. The immune system is tasked with the detection and destruction of pathogens. In the case of tau, $\alpha S$ and other protein agents, these tasks are

\section{REFERENCES}

1. About a peculiar disease of the cerebral cortex. By Alois Alzheimer, 1907 (Translated by L. Jarvik and H. Greenson). Alzheimer Dis Assoc Disord. (1987) 1:3-8.

2. Goedert M, Eisenberg DS, Crowther RA. Propagation of tau aggregates and neurodegeneration. Annu Rev Neurosci. (2017) 40:189-210. doi: 10.1146/annurev-neuro-072116-031153

3. Polymeropoulos MH, Lavedan C, Leroy E, Ide SE, Dehejia A, Dutra A, et al. Mutation in the $\alpha$-synuclein gene identified in families with Parkinson's disease. Science. (1997) 276:2045-7. doi: 10.1126/science.276.532 1.2045

4. Conway KA, Harper JD, Lansbury PT. Accelerated in vitro fibril formation by a mutant $\alpha$-synuclein linked to early-onset Parkinson disease. Nat Med. (1998) 4:1318-20. doi: 10.1038/3311

5. Karran E, De Strooper B. The amyloid cascade hypothesis: are we poised for success or failure? J Neurochem. (2016) 139(Suppl. 2):237-52. doi: $10.1111 /$ jnc. 13632 evidently not performed to a sufficient degree to resolve or limit aggregation. Notably, the detection of aggregated proteins as a threat is hindered by a lack of classical pathogen-associated molecular patterns, arising from their status as self proteins in an altered conformation. Destruction is hindered due to their physically robust and highly compacted nature, which is refractory to proteasomal degradation (159). Antibodies, either induced following active immunization or passively transferred, represent a means by which protein assemblies can be labeled as threats and then inactivated by neutralization, sequestration, or FcR-mediated effector functions. A deeper understanding of these mechanisms may provide a route to novel therapies in age-related neurodegenerative disease. Finally, the expense of long-term passive immunotherapy may ultimately prove prohibitive to its widespread clinical uptake. However, evidence of improvement in cognitive outcomes following immunotherapy would serve as a critical indicator that pathologically important processes have been targeted. In this way, passive immunotherapy may serve as proof-of-principle for future therapies, targeting the same processes, that are more suited to scaled production at affordable cost.

\section{AUTHOR CONTRIBUTIONS}

WM wrote the manuscript. TK, BT, AM, and WM prepared figures and edited the manuscript.

\section{FUNDING}

WM is supported by a Sir Henry Dale Fellowship jointly funded by the Wellcome Trust and the Royal Society (Grant Number 206248/Z/17/Z). BT receives funding from the Cambridge Trust Vice Chancellor's Award and the Hughes Hall Edwin Leong Scholarship in Life Sciences. This work has received funding from the Innovative Medicines Initiative 2 Joint Undertaking under grant agreement No. 116060 (IMPRiND). This Joint Undertaking receives support from the European Union's Horizon 2020 research and innovation programme and EFPIA. This work is supported by the Swiss State Secretariat for Education, Research and Innovation (SERI) under contract number 17.00038.

6. Tang WK, Xia D. Mutations in the human AAA + chaperone p97 and related diseases. Front Mol Biosci. (2016) 3:79. doi: 10.3389/fmolb.2016.00079

7. Kelleher RJ III, Shen J. Presenilin-1 mutations and Alzheimer's disease. Proc Natl Acad Sci USA. (2017) 114:629-31. doi: 10.1073/pnas.1619574114

8. Selkoe DJ. The molecular pathology of Alzheimer's disease. Neuron. (1991) 6:487-98.

9. Hardy JA, Higgins GA. Alzheimer's disease: the amyloid cascade hypothesis. Science. (1992) 256:184-5.

10. Herrup K. The case for rejecting the amyloid cascade hypothesis. Nat Neurosci. (2015) 18:794-9. doi: 10.1038/nn.4017

11. Congdon EE, Sigurdsson EM. Tau-targeting therapies for Alzheimer disease. Nat Rev Neurol. (2018) 14:399-415. doi: 10.1038/s41582-018-0013-z

12. Meyer-Luehmann M, Coomaraswamy J, Bolmont $T$, Kaeser S, Schaefer C, Kilger E, et al. Exogenous induction of cerebral betaamyloidogenesis is governed by agent and host. Science. (2006) 313:1781-4. doi: 10.1126/science.1131864

13. Kane MD, Lipinski WJ, Callahan MJ, Bian F, Durham RA, Schwarz RD, et al. Evidence for seeding of $\beta$-amyloid by intracerebral infusion of alzheimer 
brain extracts in $\beta$-amyloid precursor protein-transgenic mice. J Neurosci. (2000) 20:3606-11. doi: 10.1523/JNEUROSCI.20-10-03606.2000

14. Clavaguera F, Bolmont T, Crowther RA, Abramowski D, Frank S, Probst A, et al. Transmission and spreading of tauopathy in transgenic mouse brain. Nat Cell Biol. (2009) 11:909-13. doi: 10.1038/ncb1901

15. Frost B, Jacks RL, Diamond MI. Propagation of tau misfolding from the outside to the inside of a cell. J Biol Chem. (2009) 284:12845-52. doi: 10.1074/jbc.M808759200

16. Porta S, Xu Y, Restrepo CR, Kwong LK, Zhang B, Brown HJ, et al. Patientderived frontotemporal lobar degeneration brain extracts induce formation and spreading of TDP-43 pathology in vivo. Nat Commun. (2018) 9:4220. doi: 10.1038/s41467-018-06548-9

17. Masnata M, Cicchetti F. The evidence for the spread and seeding capacities of the mutant huntingtin protein in in vitro systems and their therapeutic implications. Front Neurosci. (2017) 11:647. doi: 10.3389/fnins.2017. 00647

18. Luk KC, Kehm V, Carroll J, Zhang B, O’Brien P, Trojanowski JQ, et al. Pathological $\alpha$-synuclein transmission initiates parkinson-like neurodegeneration in nontransgenic mice. Science. (2012) 338:949-53. doi: $10.1126 /$ science. 1227157

19. Volpicelli-Daley LA, Luk KC, Patel TP, Tanik SA, Riddle DM, Stieber A, et al. Exogenous $\alpha$-synuclein fibrils induce lewy body pathology leading to synaptic dysfunction and neuron death. Neuron. (2011) 72:57-71. doi: 10.1016/j.neuron.2011.08.033

20. Jucker M, Walker LC. Propagation and spread of pathogenic protein assemblies in neurodegenerative diseases. Nat Neurosci. (2018) 21:1341-9. doi: 10.1038/s41593-018-0238-6

21. Calafate S, Buist A, Miskiewicz K, Vijayan V, Daneels G, de Strooper B, et al. Synaptic contacts enhance cell-to-cell tau pathology propagation. Cell Rep. (2015) 11:1176-83. doi: 10.1016/j.celrep.2015.04.043

22. Wu JW, Hussaini SA, Bastille IM, Rodriguez GA, Mrejeru A, Rilett K, et al. Neuronal activity enhances tau propagation and tau pathology in vivo. Nat Neurosci. (2016) 19:1085-92. doi: 10.1038/nn.4328

23. Ahmed Z, Cooper J, Murray TK, Garn K, McNaughton E, Clarke H, et al. A novel in vivo model of tau propagation with rapid and progressive neurofibrillary tangle pathology: the pattern of spread is determined by connectivity, not proximity. Acta Neuropathol. (2014) 127:667-83. doi: 10.1007/s00401-014-1254-6

24. de Calignon A, Polydoro M, Suárez-Calvet M, William C, Adamowicz $\mathrm{DH}$, Kopeikina KJ, et al. Propagation of tau pathology in a model of early Alzheimer's disease. Neuron. (2012) 73:685-97. doi: 10.1016/j.neuron.2011.11.033

25. Liu L, Drouet V, Wu JW, Witter MP, Small SA, Clelland C, et al. Transsynaptic spread of tau pathology in vivo. PLoS ONE. (2012) 7:e31302. doi: 10.1371/journal.pone. 0031302

26. Cope TE, Rittman T, Borchert RJ, Jones PS, Vatansever D, Allinson $\mathrm{K}$, et al. Tau burden and the functional connectome in Alzheimer's disease and progressive supranuclear palsy. Brain. (2018) 141:550-67. doi: 10.1093/brain/awx347

27. Wang Y, Balaji V, Kaniyappan S, Krüger L, Irsen S, Tepper K, et al. The release and trans-synaptic transmission of Tau via exosomes. Mol Neurodegen. (2017) 12:5. doi: 10.1186/s13024-016-0143-y

28. Polanco JC, Scicluna BJ, Hill AF, Götz J. Extracellular vesicles isolated from the brains of rTg4510 mice seed tau protein aggregation in a threshold-dependent manner. J Biol Chem. (2016) 291:12445-66. doi: 10.1074/jbc.M115.709485

29. Abounit S, Wu JW, Duff K, Victoria GS, Zurzolo C. Tunneling nanotubes: a possible highway in the spreading of tau and other prionlike proteins in neurodegenerative diseases. Prion. (2016) 10:344-51. doi: 10.1080/19336896.2016.1223003

30. Tardivel M, Bégard S, Bousset L, Dujardin S, Coens A, Melki R, et al. Tunneling nanotube (TNT)-mediated neuron-to neuron transfer of pathological Tau protein assemblies. Acta Neuropathol Commun. (2016) 4:117. doi: 10.1186/s40478-016-0386-4

31. Walsh DM, Selkoe DJ. A critical appraisal of the pathogenic protein spread hypothesis of neurodegeneration. Nat Rev Neurosci. (2016) 17:251-60. doi: $10.1038 / \mathrm{nrn} .2016 .13$
32. Neuwelt EA, Bauer B, Fahlke C, Fricker G, Iadecola C, Janigro D, et al. Engaging neuroscience to advance translational research in brain barrier biology. Nat Rev Neurosci. (2011) 12:169-82. doi: 10.1038/nrn2995

33. Louveau A, Smirnov I, Keyes TJ, Eccles JD, Rouhani SJ, Peske JD, et al. Structural and functional features of central nervous system lymphatic vessels. Nature. (2015) 523:337-41. doi: 10.1038/nature14432

34. Aspelund A, Antila S, Proulx ST, Karlsen TV, Karaman S, Detmar M, et al. A dural lymphatic vascular system that drains brain interstitial fluid and macromolecules. J Exp Med. (2015) 212:991-9. doi: 10.1084/jem.20142290

35. Schlachetzki F, Zhu C, Pardridge WM. Expression of the neonatal Fc receptor (FcRn) at the blood-brain barrier. J Neurochem. (2002) 81:203-6. doi: 10.1046/j.1471-4159.2002.00840.x

36. Zhang Y, Pardridge WM. Mediated efflux of IgG molecules from brain to blood across the blood-brain barrier. J Neuroimmunol. (2001) 114:168-72. doi: 10.1016/S0165-5728(01)00242-9

37. Cooper PR, Ciambrone GJ, Kliwinski CM, Maze E, Johnson L, Li Q, et al. Efflux of monoclonal antibodies from rat brain by neonatal Fc receptor, FcRn. Brain Res. (2013) 1534:13-21. doi: 10.1016/j.brainres.2013.08.035

38. Deane R, Sagare A, Hamm K, Parisi M, LaRue B, Guo H, et al. IgGassisted age-dependent clearance of Alzheimer's amyloid beta peptide by the blood-brain barrier neonatal Fc receptor. J Neurosci. (2005) 25:11495-503. doi: 10.1523/JNEUROSCI.3697-05.2005

39. Abuqayyas L, Balthasar JP. Investigation of the role of Fc $\gamma R$ and FcRn in mAb distribution to the brain. Mol Pharma. (2013) 10:1505-13. doi: $10.1021 / \mathrm{mp} 300214 \mathrm{k}$

40. Bergman I, Burckart GJ, Pohl CR, Venkataramanan R, Barmada MA, Griffin $\mathrm{JA}$, et al. Pharmacokinetics of IgG and IgM anti-ganglioside antibodies in rats and monkeys after intrathecal administration. J Pharmacol Exp Ther. (1998) 284:111-15.

41. Balint B, Vincent A, Meinck H-M, Irani SR, Bhatia KP. Movement disorders with neuronal antibodies: syndromic approach, genetic parallels and pathophysiology. Brain. (2018) 141:13-36. doi: 10.1093/brain/awx189

42. Giannoccaro MP, Crisp SJ, Vincent A. Antibody-mediated central nervous system diseases. Brain Neurosci Adv. (2018) 2:1-10. doi: $10.1177 / 2398212818817497$

43. Geis C, Weishaupt A, Grünewald B, Wultsch T, Reif A, Gerlach M, et al. Human stiff-person syndrome IgG induces anxious behavior in rats. PLoS ONE. (2011) 6:e16775. doi: 10.1371/journal.pone.0016775

44. Gable MS, Sheriff H, Dalmau J, Tilley DH, Glaser CA. The frequency of autoimmune $\mathrm{N}$-methyl-D-aspartate receptor encephalitis surpasses that of individual viral etiologies in young individuals enrolled in the California Encephalitis Project. Clin Infect Dis. (2012) 54:899-904. doi: $10.1093 / \mathrm{cid} / \mathrm{cir} 1038$

45. Bard F, Cannon C, Barbour R, Burke R-L, Games D, Grajeda H, et al. Peripherally administered antibodies against amyloid $\beta$-peptide enter the central nervous system and reduce pathology in a mouse model of Alzheimer disease. Nat Med. (2000) 6:916-19. doi: 10.1038/78682

46. Sevigny J, Chiao P, Bussière T, Weinreb PH, Williams L, Maier M, et al. The antibody aducanumab reduces $\mathrm{A} \beta$ plaques in Alzheimer's disease. Nature. (2016) 537:50-6. doi: 10.1038/nature19323

47. Ostrowitzki S, Deptula D, Thurfjell L, Barkhof F, Bohrmann B, Brooks DJ, et al. Mechanism of amyloid removal in patients with Alzheimer disease treated with gantenerumab. Arch Neurol. (2012) 69:198-207. doi: 10.1001/archneurol.2011.1538

48. Salloway S, Sperling R, Fox NC, Blennow K, Klunk W, Raskind M, et al. Two phase 3 trials of bapineuzumab in mild-to-moderate Alzheimer's disease. $N$ Engl J Med. (2014) 370:322-33. doi: 10.1056/NEJMoa1304839

49. Solomon B, Koppel R, Hanan E, Katzav T. Monoclonal antibodies inhibit in vitro fibrillar aggregation of the Alzheimer beta-amyloid peptide. Proc Natl Acad Sci USA. (1996) 93:452-5.

50. Bruhns P, Jönsson F. Mouse and human FcR effector functions. Immunol Rev. (2015) 268:25-51. doi: 10.1111/imr.12350

51. Vidarsson G, Dekkers G, Rispens T. IgG subclasses and allotypes: from structure to effector functions. Front Immunol. (2014) 5:520. doi: $10.3389 /$ fimmu. 2014.00520

52. Charles A Janeway J, Travers P, Walport M, Shlomchik MJ. Structural variation in immunoglobulin constant regions. In: Immunobiology: The 
Immune System in Health and Disease. 5th ed (2001) Available online at: https://www.ncbi.nlm.nih.gov/books/NBK27106/ (accessed April 26, 2019).

53. van der Zee JS, van Swieten P, Aalberse RC. Inhibition of complement activation by IgG4 antibodies. Clin Exp Immunol. (1986) 64:415-22.

54. van der Neut Kolfschoten M, Schuurman J, Losen M, Bleeker WK, MartínezMartínez P, Vermeulen E, et al. Anti-inflammatory activity of human IgG4 antibodies by dynamic Fab arm exchange. Science. (2007) 317:1554-7. doi: 10.1126/science.1144603

55. Keeble AH, Khan Z, Forster A, James LC. TRIM21 is an IgG receptor that is structurally, thermodynamically, and kinetically conserved. Proc Natl Acad Sci USA. (2008) 105:6045-50. doi: 10.1073/pnas.0800159105

56. Mallery DL, McEwan WA, Bidgood SR, Towers GJ, Johnson CM, James LC. Antibodies mediate intracellular immunity through tripartite motifcontaining 21 (TRIM21). Proc Natl Acad Sci USA. (2010) 107:19985-90. doi: $10.1073 /$ pnas. 1014074107

57. Bidgood SR, Tam JCH, McEwan WA, Mallery DL, James LC, Translocalized IgA mediates neutralization and stimulates innate immunity inside infected cells. Proc Natl Acad Sci USA. (2014) 111:13463-8. doi: 10.1073/pnas.1410980111

58. McEwan WA, Tam JCH, Watkinson RE, Bidgood SR, Mallery DL, James LC. Intracellular antibody-bound pathogens stimulate immune signaling via the Fc receptor TRIM21. Nat Immunol. (2013) 14:327-36. doi: 10.1038/ni.2548

59. Fletcher AJ, Mallery DL, Watkinson RE, Dickson CF, James LC. Sequential ubiquitination and deubiquitination enzymes synchronize the dual sensor and effector functions of TRIM21. Proc Natl Acad Sci USA. (2015) 112:10014-19. doi: 10.1073/pnas.1507534112

60. McEwan WA, Hauler F, Williams CR, Bidgood SR, Mallery DL, Crowther RA, et al. Regulation of virus neutralization and the persistent fraction by TRIM21. J Virol. (2012) 86:8482-91. doi: 10.1128/JVI.00728-12

61. McEwan WA. Surveillance for intracellular antibody by cytosolic Fc receptor TRIM21. Antibodies. (2016) 5:21. doi: 10.3390/antib5040021

62. Fuller JP, Stavenhagen JB, Teeling JL. New roles for Fc receptors in neurodegeneration-the impact on Immunotherapy for Alzheimer's Disease. Front Neurosci. (2014) 8:235. doi: 10.3389/fnins.2014.00235

63. Bouras C, Riederer BM, Kövari E, Hof PR, Giannakopoulos P. Humoral immunity in brain aging and Alzheimer's disease. Brain Res Brain Res Rev. (2005) 48:477-87. doi: 10.1016/j.brainresrev.2004.09.009

64. Zhang Y, Chen K, Sloan SA, Bennett ML, Scholze AR, O'Keeffe S, et al. An RNA-sequencing transcriptome and splicing database of glia, neurons, and vascular cells of the cerebral cortex. J Neurosci. (2014) 34:11929-47. doi: 10.1523/JNEUROSCI.1860-14.2014

65. Lee S-H, Le Pichon CE, Adolfsson O, Gafner V, Pihlgren M, Lin H, et al. Antibody-mediated targeting of tau in vivo does not require effector function and microglial engagement. Cell Rep. (2016) 16:1690-700. doi: 10.1016/j.celrep.2016.06.099

66. Nakamura K, Hirai H, Torashima T, Miyazaki T, Tsurui H, Xiu Y, et al. CD3 and immunoglobulin G Fc receptor regulate cerebellar functions. Mol Cell Biol. (2007) 27:5128-34. doi: 10.1128/MCB.01072-06

67. Gunasekaran M, Chatterjee PK, Shih A, Imperato GH, Addorisio M, Kumar G, et al. Immunization elicits antigen-specific antibody sequestration in dorsal root ganglia sensory neurons. Front Immunol. (2018) 9:638. doi: $10.3389 /$ fimmu.2018.00638

68. Andoh T, Kuraishi Y. Direct action of immunoglobulin G on primary sensory neurons through Fc gamma receptor I. FASEB J. (2004) 18:182-4. doi: 10.1096/fj.02-1169fje

69. Mohamed HA, Mosier DR, Zou LL, Siklós L, Alexianu ME, Engelhardt JI, et al. Immunoglobulin Fc gamma receptor promotes immunoglobulin uptake, immunoglobulin-mediated calcium increase, and neurotransmitter release in motor neurons. J Neurosci Res. (2002) 69:110-16. doi: 10.1002/jnr.10271

70. McEwan WA, Falcon B, Vaysburd M, Clift D, Oblak AL, Ghetti B, et al. Cytosolic Fc receptor TRIM21 inhibits seeded tau aggregation. Proc Natl Acad Sci USA. (2017) 114:574-9. doi: 10.1073/pnas.1607215114

71. Martin E, Boucher C, Fontaine B, Delarasse C. Distinct inflammatory phenotypes of microglia and monocyte-derived macrophages in Alzheimer's disease models: effects of aging and amyloid pathology. Aging Cell. (2017) 16:27-38. doi: 10.1111/acel.12522
72. Tooyama I, Kimura H, Akiyama H, McGeer PL. Reactive microglia express class I and class II major histocompatibility complex antigens in Alzheimer's disease. Brain Res. (1990) 523:273-80.

73. Vogel SN, Finbloom DS, English KE, Rosenstreich DL, Langreth SG. Interferon-induced enhancement of macrophage $\mathrm{Fc}$ receptor expression: beta-interferon treatment of $\mathrm{C} 3 \mathrm{H} / \mathrm{HeJ}$ macrophages results in increased numbers and density of Fc receptors. J Immunol. (1983) 130:1210-14.

74. Mo J-J, Li J, Yang Z, Liu Z, Feng J-S. Efficacy and safety of antiamyloid- $\beta$ immunotherapy for Alzheimer's disease: a systematic review and network meta-analysis. Ann Clin Transl Neurol. (2017) 4:931-42. doi: $10.1002 /$ acn 3.469

75. Das P, Howard V, Loosbrock N, Dickson D, Murphy MP, Golde TE. Amyloid- $\beta$ immunization effectively reduces amyloid deposition in FcR $\gamma$-/- knock-out mice. J Neurosci. (2003) 23:8532-8. doi: 10.1523/JNEUROSCI.23-24-08532.2003

76. Tamura Y, Hamajima K, Matsui K, Yanoma S, Narita M, Tajima N, et al. The $F\left(a b^{\prime}\right) 2$ fragment of an $A \beta$-specific monoclonal antibody reduces $A \beta$ deposits in the brain. Neurobiol Dis. (2005) 20:541-9. doi: 10.1016/j.nbd.2005.04.007

77. Bacskai BJ, Kajdasz ST, McLellan ME, Games D, Seubert P, Schenk $\mathrm{D}$, et al. Non-Fc-mediated mechanisms are involved in clearance of amyloid- $\beta$ in vivo by immunotherapy. $J$ Neurosci. (2002) 22:7873-8. doi: 10.1523/JNEUROSCI.22-18-07873.2002

78. Tran HT, Chung CH-Y, Iba M, Zhang B, Trojanowski JQ, Luk KC, et al. $\alpha$-Synuclein immunotherapy blocks uptake and templated propagation of misfolded $\alpha$-synuclein and neurodegeneration. Cell Rep. (2014) 7:2054-65. doi: 10.1016/j.celrep.2014.05.033

79. Funk KE, Mirbaha H, Jiang H, Holtzman DM, Diamond MI. Distinct therapeutic mechanisms of tau antibodies promoting microglial clearance versus blocking neuronal uptake. J Biol Chem. (2015) 290:21652-62. doi: 10.1074/jbc.M115.657924

80. Pradier L, Blanchard-Brégeon V, Bohme A, Debeir T, Menager J, Benoit $\mathrm{P}$, et al. SAR228810: an antibody for protofibrillar amyloid $\beta$ peptide designed to reduce the risk of amyloid-related imaging abnormalities (ARIA). Alzheimers Res Ther. (2018) 10:117. doi: 10.1186/s13195-018-0447-y

81. Delnomdedieu M, Duvvuri S, Li DJ, Atassi N, Lu M, Brashear HR, et al. FirstIn-Human safety and long-term exposure data for AAB-003 (PF-05236812) and biomarkers after intravenous infusions of escalating doses in patients with mild to moderate Alzheimer's disease. Alzheimers Res Ther. (2016) 8:12. doi: 10.1186/s13195-016-0177-y

82. van Dyck CH. Anti-Amyloid- $\beta$ monoclonal antibodies for Alzheimer's disease: pitfalls and promise. Biol Psychiatry. (2018) 83:311-9. doi: 10.1016/j.biopsych.2017.08.010

83. Gilman S, Koller M, Black RS, Jenkins L, Griffith SG, Fox NC, et al. Clinical effects of Abeta immunization (AN1792) in patients with AD in an interrupted trial. Neurology. (2005) 64:1553-62. doi: 10.1212/01.WNL.0000159740.16984.3C

84. Rinne JO, Brooks DJ, Rossor MN, Fox NC, Bullock R, Klunk WE, et al. 11CPiB PET assessment of change in fibrillar amyloid- $\beta$ load in patients with Alzheimer's disease treated with bapineuzumab: a phase 2, double-blind, placebo-controlled, ascending-dose study. Lancet Neurol. (2010) 9:363-72. doi: 10.1016/S1474-4422(10)70043-0

85. Sperling R, Salloway S, Brooks DJ, Tampieri D, Barakos J, Fox NC, et al. Amyloid-related imaging abnormalities in patients with Alzheimer's disease treated with bapineuzumab: a retrospective analysis. Lancet Neurol. (2012) 11:241-9. doi: 10.1016/S1474-4422(12)70015-7

86. Bateman RJ, Benzinger TL, Berry S, Clifford DB, Duggan C, Fagan AM, et al. The DIAN-TU next generation Alzheimer's prevention trial: adaptive design and disease progression model. Alzheimer's Dement. (2017) 13:8-19. doi: 10.1016/j.jalz.2016.07.005

87. Sperling RA, Rentz DM, Johnson KA, Karlawish J, Donohue M, Salmon DP, et al. The A4 study: stopping AD before symptoms begin? Sci Transl Med. (2014) 6:228fs13. doi: 10.1126/scitranslmed.3007941

88. Masliah E, Rockenstein E, Adame A, Alford M, Crews L, Hashimoto M, et al. Effects of alpha-synuclein immunization in a mouse model of Parkinson's disease. Neuron. (2005) 46:857-68. doi: 10.1016/j.neuron.2005.05.010

89. Asuni AA, Boutajangout A, Quartermain D, Sigurdsson EM. Immunotherapy targeting pathological tau conformers in a tangle mouse 
model reduces brain pathology with associated functional improvements. $J$ Neurosci. (2007) 27:9115-29. doi: 10.1523/JNEUROSCI.2361-07.2007

90. Boutajangout A, Quartermain D, Sigurdsson EM. Immunotherapy targeting pathological tau prevents cognitive decline in a new tangle mouse model. $J$ Neurosci. (2010) 30:16559-66. doi: 10.1523/JNEUROSCI.4363-10.2010

91. Theunis C, Crespo-Biel N, Gafner V, Pihlgren M, López-Deber MP, Reis $\mathrm{P}$, et al. Efficacy and safety of A liposome-based vaccine against protein tau, assessed in tau.P301L mice that model tauopathy. PLoS ONE. (2013) 8:e72301. doi: 10.1371/journal.pone.0072301

92. Bi M, Ittner A, Ke YD, Götz J, Ittner LM. Tau-targeted immunization impedes progression of neurofibrillary histopathology in aged P301l tau transgenic mice. PLoS ONE. (2011) 6:e26860. doi: 10.1371/journal.pone. 0026860

93. Boimel M, Grigoriadis N, Lourbopoulos A, Haber E, Abramsky O, Rosenmann H. Efficacy and safety of immunization with phosphorylated tau against neurofibrillary tangles in mice. Exp Neurol. (2010) 224:472-85. doi: 10.1016/j.expneurol.2010.05.010

94. Troquier L, Caillierez R, Burnouf S, Fernandez-Gomez FJ, Grosjean M-E, Zommer N, et al. Targeting phospho-Ser 422 by active tau immunotherapy in the THYTau22 mouse model: a suitable therapeutic approach. Curr Alzheimer Res. (2012) 9:397-405. doi: 10.2174/156720512800492503

95. Yanamandra K, Kfoury N, Jiang H, Mahan TE, Ma S, Maloney SE, et al. Anti-tau antibodies that block tau aggregate seeding in vitro markedly decrease pathology and improve cognition in vivo. Neuron. (2013) 80:40214. doi: 10.1016/j.neuron.2013.07.046

96. Yanamandra K, Jiang H, Mahan TE, Maloney SE, Wozniak DF, Diamond MI, et al. Anti-tau antibody reduces insoluble tau and decreases brain atrophy. Ann Clin Transl Neurol. (2015) 2:278-88. doi: 10.1002/acn3.176

97. Ittner A, Bertz J, Suh LS, Stevens CH, Götz J, Ittner LM. Tau-targeting passive immunization modulates aspects of pathology in tau transgenic mice. J Neurochem. (2015) 132:135-45. doi: 10.1111/jnc.12821

98. Sankaranarayanan S, Barten DM, Vana L, Devidze N, Yang L, Cadelina G, et al. Passive immunization with phospho-tau antibodies reduces tau pathology and functional deficits in two distinct mouse tauopathy models. PLoS ONE. (2015) 10:e0125614. doi: 10.1371/journal.pone.0125614

99. Congdon EE, Gu J, Sait HBR, Sigurdsson EM. Antibody uptake into neurons occurs primarily via clathrin-dependent $\mathrm{Fc} \gamma$ receptor endocytosis and is a prerequisite for acute tau protein clearance. J Biol Chem. (2013) 288:35452-65. doi: 10.1074/jbc.M113.4 91001

100. Collin L, Bohrmann B, Göpfert U, Oroszlan-Szovik K, Ozmen L, Grüninger F. Neuronal uptake of tau/pS422 antibody and reduced progression of tau pathology in a mouse model of Alzheimer's disease. Brain. (2014) 137:283446. doi: 10.1093/brain/awu213

101. Plotkin SA. Complex correlates of protection after vaccination. Clin Infect Dis. (2013) 56:1458-65. doi: 10.1093/cid/cit048

102. Klasse PJ, Moore JP. Good CoP, bad CoP? Interrogating the immune responses to primate lentiviral vaccines. Retrovirology. (2012) 9:80. doi: $10.1186 / 1742-4690-9-80$

103. Pedersen JT, Sigurdsson EM. Tau immunotherapy for Alzheimer's disease. Trends Mol Med. (2015) 21:394-402. doi: 10.1016/j.molmed.2015.03.003

104. Brundin P, Dave KD, Kordower JH. Therapeutic approaches to target alpha-synuclein pathology. Exp Neurol. (2017) 298:225-35. doi: 10.1016/j.expneurol.2017.10.003

105. Kontsekova E, Zilka N, Kovacech B, Skrabana R, Novak M. Identification of structural determinants on tau protein essential for its pathological function: novel therapeutic target for tau immunotherapy in Alzheimer's disease. Alzheimer's Res Ther. (2014) 6:45. doi: 10.1186/alzrt277

106. Kontsekova E, Zilka N, Kovacech B, Novak P, Novak M. First-in-man tau vaccine targeting structural determinants essential for pathological tau-tau interaction reduces tau oligomerisation and neurofibrillary degeneration in an Alzheimer's disease model. Alzheimer's Res Ther. (2014) 6:44. doi: $10.1186 /$ alzrt278

107. Novak P, Schmidt R, Kontsekova E, Zilka N, Kovacech B, Skrabana R, et al. Safety and immunogenicity of the tau vaccine AADvac1 in patients with Alzheimer's disease: a randomised, double-blind, placebo-controlled, phase 1 trial. Lancet Neurol. (2017) 16:123-34. doi: 10.1016/S1474-4422(16)3 0331-3
108. Novak P, Kontsekova E, Zilka N, Novak M. Ten Years of tau-targeted immunotherapy: the path walked and the roads ahead. Front Neurosci. (2018) 12:798. doi: 10.3389/fnins.2018.00798

109. Ondrus M, Novak P. Design of the phase II clinical study of the tau vaccine AADvac1 in patients with mild Alzheimer's disease. Neurobiol Aging. (2016) 39:S26. doi: 10.1016/j.neurobiolaging.2016.01.115

110. Jicha GA, Lane E, Vincent I, Otvos L, Hoffmann R, Davies P. A conformation- and phosphorylation-dependent antibody recognizing the paired helical filaments of Alzheimer's disease. J Neurochem. (1997) 69:208795. doi: 10.1046/j.1471-4159.1997.69052087.x

111. Czerkowicz J, Chen W, Wang Q, Shen C, Wager C, Stone I, et al. Pantau antibody BIIb076 exhibits promising safety and biomarker profile in cynomolgus monkey toxicity study. Alzheimer's Dement J Alzheimer's Assoc. (2017) 13:P1271. doi: 10.1016/j.jalz.2017.06.1903

112. Bright J, Hussain S, Dang V, Wright S, Cooper B, Byun T, et al. Human secreted tau increases amyloid-beta production. Neurobiol Aging. (2015) 36:693-709. doi: 10.1016/j.neurobiolaging.2014.09.007

113. Kfoury N, Holmes BB, Jiang H, Holtzman DM, Diamond MI. Trans-cellular propagation of Tau aggregation by fibrillar species. J Biol Chem. (2012) 287:19440-51. doi: 10.1074/jbc.M112.346072

114. Lo M, Kim HS, Tong RK, Bainbridge TW, Vernes J-M, Zhang $\mathrm{Y}$, et al. Effector-attenuating substitutions that maintain antibody stability and reduce toxicity in mice. $J$ Biol Chem. (2017) 292:3900-8. doi: $10.1074 /$ jbc.M116.767749

115. Adolfsson O, Pihlgren M, Toni N, Varisco Y, Buccarello AL, Antoniello K, et al. An effector-reduced anti- $\beta$-amyloid $(A \beta)$ antibody with unique $A \beta$ binding properties promotes neuroprotection and glial engulfment of $A \beta$. J Neurosci. (2012) 32:9677-89. doi: 10.1523/JNEUROSCI.4742-11.2012

116. Treating Tau: Finally, Clinical Candidates Are Stepping into the Ring. ALZFORUM. Available online at: https://www.alzforum.org/news/ conference-coverage/treating-tau-finally-clinical-candidates-are-steppingring (accessed April 25, 2019).

117. To Block Tau's Proteopathic Spread, Antibody Must Attack its MidRegion. ALZFORUM. Available online at: https://www.alzforum.org/news/ conference-coverage/block-taus-proteopathic-spread-antibody-mustattack-its-mid-region (accessed April 25, 2019).

118. Jicha GA, Bowser R, Kazam IG, Davies P. Alz-50 and MC-1, a new monoclonal antibody raised to paired helical filaments, recognize conformational epitopes on recombinant tau. J Neurosci Res. (1997) 48:12832.

119. Fitzpatrick AWP, Falcon B, He S, Murzin AG, Murshudov G, Garringer HJ, et al. Cryo-EM structures of tau filaments from Alzheimer's disease. Nature. (2017) 547:185-90. doi: 10.1038/nature23002

120. Alam R, Driver D, Wu S, Lozano E, Key SL, Hole JT, et al. Preclinical characterization of an antibody [LY3303560] targeting aggregated tau. Alzheimer's Dement J Alzheimer's Assoc. (2017) 13:P592-3. doi: 10.1016/j.jalz.2017.07.227

121. Masliah E, Rockenstein E, Mante M, Crews L, Spencer B, Adame A, et al. Passive immunization reduces behavioral and neuropathological deficits in an alpha-synuclein transgenic model of Lewy body disease. PLOS ONE. (2011) 6:e19338. doi: 10.1371/journal.pone.0019338

122. Games D, Valera E, Spencer B, Rockenstein E, Mante M, Adame $A$, et al. Reducing C-terminal-truncated alpha-synuclein by immunotherapy attenuates neurodegeneration and propagation in Parkinson's disease-like models. J Neurosci. (2014) 34:9441-54. doi: 10.1523/JNEUROSCI.5314-13.2014

123. Schenk DB, Koller M, Ness DK, Griffith SG, Grundman M, Zago $\mathrm{W}$, et al. First-in-human assessment of PRX002, an anti- $\alpha$-synuclein monoclonal antibody, in healthy volunteers. Mov Disord. (2017) 32:211-18. doi: $10.1002 / \mathrm{mds} .26878$

124. DeMattos RB, Bales KR, Cummins DJ, Dodart JC, Paul SM, Holtzman DM. Peripheral anti-A beta antibody alters CNS and plasma A beta clearance and decreases brain A beta burden in a mouse model of Alzheimer's disease. Proc Natl Acad Sci USA. (2001) 98:8850-5. doi: 10.1073/pnas.151261398

125. Landen JW, Cohen S, Billing CB, Cronenberger C, Styren S, Burstein AH, et al. Multiple-dose ponezumab for mild-to-moderate Alzheimer's disease: safety and efficacy. Alzheimer's Dement Transl Res Clin Interv. (2017) 3:33947. doi: 10.1016/j.trci.2017.04.003 
126. Willis BA, Sundell K, Lachno DR, Ferguson-Sells LR, Case MG, Holdridge $\mathrm{K}$, et al. Central pharmacodynamic activity of solanezumab in mild Alzheimer's disease dementia. Alzheimers Dement. (2018) 4:652-60. doi: 10.1016/j.trci.2018.10.001

127. Doody RS, Thomas RG, Farlow M, Iwatsubo T, Vellas B, Joffe S, et al. Phase 3 trials of solanezumab for mild-to-moderate Alzheimer's disease. (2014) 370:311-21. doi: 10.1056/NEJMoa1312889

128. Mably AJ, Liu W, Mc Donald JM, Dodart J-C, Bard F, Lemere CA, et al. Anti-A $\beta$ antibodies incapable of reducing cerebral $A \beta$ oligomers fail to attenuate spatial reference memory deficits in J20 mice. Neurobiol Dis. (2015) 82:372-84. doi: 10.1016/j.nbd.2015.07.008

129. Henderson SJ, Andersson C, Narwal R, Janson J, Goldschmidt TJ, Appelkvist $\mathrm{P}$, et al. Sustained peripheral depletion of amyloid- $\beta$ with a novel form of neprilysin does not affect central levels of amyloid- $\beta$. Brain. (2014) 137:55364. doi: 10.1093/brain/awt308

130. Thakker DR, Weatherspoon MR, Harrison J, Keene TE, Lane DS, Kaemmerer WF, et al. Intracerebroventricular amyloid-beta antibodies reduce cerebral amyloid angiopathy and associated micro-hemorrhages in aged Tg2576 mice. Proc Natl Acad Sci USA. (2009) 106:4501-6. doi: 10.1073/pnas.0813404106

131. Paganetti P, Reichwald J, Bleckmann D, Abramowski D, Ammaturo D, Barske $C$, et al. Transgenic expression of $\beta 1$ antibody in brain neurons impairs age-dependent amyloid deposition in APP23 mice. Neurobiol Aging. (2013) 34:2866-78. doi: 10.1016/j.neurobiolaging.2013.06.013

132. Liu W, Zhao L, Blackman B, Parmar M, Wong MY, Woo T, et al. Vectored intracerebral immunization with the anti-tau monoclonal antibody PHF1 markedly reduces tau pathology in mutant tau transgenic mice. J Neurosci. (2016) 36:12425-35. doi: 10.1523/JNEUROSCI.2016-16.2016

133. Shimada M, Abe S, Takahashi T, Shiozaki K, Okuda M, Mizukami $\mathrm{H}$, et al. Prophylaxis and treatment of Alzheimer's disease by delivery of an adeno-associated virus encoding a monoclonal antibody targeting the amyloid beta protein. PLoS ONE. (2013) 8:e57606. doi: 10.1371/ journal.pone.0057606

134. Burnet FM, Keogh EV, Lush D. The immunological reactions of the filterable viruses. Aust J Exp Biol Med Sci. (1937) 15:227-368. doi: 10.1038/icb.1937.23

135. Klasse PJ. Neutralization of virus infectivity by antibodies: old problems in new perspectives. Adv Biol. (2014) 2014:157895. doi: 10.1155/2014/157895

136. Evans LD, Wassmer T, Fraser G, Smith J, Perkinton M, Billinton A, et al. Extracellular monomeric and aggregated tau efficiently enter human neurons through overlapping but distinct pathways. Cell Rep. (2018) 22:3612-24. doi: 10.1016/j.celrep.2018.03.021

137. Verheyen A, Diels A, Dijkmans J, Oyelami T, Meneghello G, Mertens L, et al. Using human iPSC-derived neurons to model TAU aggregation. PLoS ONE. (2015) 10:e0146127. doi: 10.1371/journal.pone.0146127

138. Mascola JR, Lewis MG, Stiegler G, Harris D, VanCott TC, Hayes $\mathrm{D}$, et al. Protection of macaques against pathogenic simian/human immunodeficiency virus $89.6 \mathrm{PD}$ by passive transfer of neutralizing antibodies. J Virol. (1999) 73:4009-18.

139. Shibata R, Igarashi T, Haigwood N, Buckler-White A, Ogert R, Ross W, et al. Neutralizing antibody directed against the HIV-1 envelope glycoprotein can completely block HIV-1/SIV chimeric virus infections of macaque monkeys. Nat Med. (1999) 5:204-10. doi: 10.1038/5568

140. Johnson GV, Seubert P, Cox TM, Motter R, Brown JP, Galasko D. The tau protein in human cerebrospinal fluid in Alzheimer's disease consists of proteolytically derived fragments. J Neurochem. (1997) 68:430-3.

141. Goedert M, Spillantini MG, Jakes R, Rutherford D, Crowther RA. Multiple isoforms of human microtubule-associated protein tau: sequences and localization in neurofibrillary tangles of Alzheimer's disease. Neuron. (1989) 3:519-26.

142. Mao X, Ou MT, Karuppagounder SS, Kam T-I, Yin X, Xiong Y, et al. Pathological $\alpha$-synuclein transmission initiated by binding lymphocyteactivation gene 3. Science. (2016) 353:aah3374. doi: 10.1126/science.aah3374

143. Ihse E, Yamakado H, van Wijk XM, Lawrence R, Esko JD, Masliah E. Cellular internalization of alpha-synuclein aggregates by cell surface heparan sulfate depends on aggregate conformation and cell type. Sci Rep. (2017) 7:9008. doi: 10.1038/s41598-017-08720-5
144. Rauch JN, Chen JJ, Sorum AW, Miller GM, Sharf T, See SK, et al. Tau internalization is regulated by $6-\mathrm{O}$ sulfation on heparan sulfate proteoglycans. (HSPGs). Sci Rep. (2018) 8:6382. doi: 10.1038/s41598-018-24904-z

145. Holmes BB, DeVos SL, Kfoury N, Li M, Jacks R, Yanamandra K, et al. Heparan sulfate proteoglycans mediate internalization and propagation of specific proteopathic seeds. Proc Natl Acad Sci USA. (2013) 110:E3138-47. doi: 10.1073/pnas.1301440110

146. Flavin WP, Bousset L, Green ZC, Chu Y, Skarpathiotis S, Chaney MJ, et al. Endocytic vesicle rupture is a conserved mechanism of cellular invasion by amyloid proteins. Acta Neuropathol. (2017) 134:629-53. doi: 10.1007/s00401-017-1722-x

147. Falcon B, Noad J, McMahon H, Randow F, Goedert M. Galectin-8-mediated selective autophagy protects against seeded tau aggregation. J Biol Chem. (2018) 293:2438-51. doi: 10.1074/jbc.M117.809293

148. Vaysburd M, Watkinson RE, Cooper H, Reed M, O'Connell K, Smith J, Cruickshanks J, et al. Intracellular antibody receptor TRIM21 prevents fatal viral infection. Proc Natl Acad Sci USA. (2013) 110:12397-401. doi: $10.1073 /$ pnas. 1301918110

149. Watkinson RE, McEwan WA, Tam JCH, Vaysburd M, James LC. TRIM21 promotes cGAS and RIG-I sensing of viral genomes during infection by antibody-opsonized virus. PLoS Pathog. (2015) 11:e1005253. doi: 10.1371/journal.ppat.1005253

150. Luisoni S, Greber UF. 2 - biology of adenovirus cell entry: receptors, pathways, mechanisms. In: Curiel DT, ed Adenoviral Vectors for Gene Therapy. 2nd ed. San Diego, CA: Academic Press (2016). p. 27-58.

151. Schober D, Kronenberger P, Prchla E, Blaas D, Fuchs R. Major and minor receptor group human rhinoviruses penetrate from endosomes by different mechanisms. J Virol. (1998) 72:1354-64.

152. Majerova P, Zilkova M, Kazmerova Z, Kovac A, Paholikova K, Kovacech B, et al. Microglia display modest phagocytic capacity for extracellular tau oligomers. J Neuroinflammation. (2014) 11:161. doi: 10.1186/s12974-014-0161-z

153. Lee H-J, Suk J-E, Bae E-J, Lee S-J. Clearance and deposition of extracellular alpha-synuclein aggregates in microglia. Biochem Biophys Res Commun. (2008) 372:423-8. doi: 10.1016/j.bbrc.2008.05.045

154. Luo W, Liu W, Hu X, Hanna M, Caravaca A, Paul SM. Microglial internalization and degradation of pathological tau is enhanced by an antitau monoclonal antibody. Sci Rep. (2015) 5:11161. doi: 10.1038/srep11161

155. Bae E-J, Lee H-J, Rockenstein E, Ho D-H, Park E-B, Yang N-Y, et al. Antibody-aided clearance of extracellular $\alpha$-synuclein prevents cell-to-cell aggregate transmission. J Neurosci. (2012) 32:13454-69. doi: 10.1523/JNEUROSCI.1292-12.2012

156. Gu J, Congdon EE, Sigurdsson EM. Two novel tau antibodies targeting the $396 / 404$ region are primarily taken up by neurons and reduce tau protein pathology. J Biol Chem. (2013) 288:33081-95. doi: 10.1074/jbc.M113.494922

157. Kondo A, Shahpasand K, Mannix R, Qiu J, Moncaster J, Chen C-H, et al. Antibody against early driver of neurodegeneration cis P-tau blocks brain injury and tauopathy. Nature. (2015) 523:431-6. doi: 10.1038/nature14658

158. Clift D, McEwan WA, Labzin LI, Konieczny V, Mogessie B, James LC, et al. A method for the acute and rapid degradation of endogenous proteins. Cell. (2017) 171:1692-706.e18. doi: 10.1016/j.cell.2017.10.033

159. Rubinsztein DC. The roles of intracellular protein-degradation pathways in neurodegeneration. Nature. (2006) 443:780-6. doi: 10.1038/nature05291

Conflict of Interest Statement: The authors declare that the research was conducted in the absence of any commercial or financial relationships that could be construed as a potential conflict of interest.

Copyright (C) 2019 Katsinelos, Tuck, Mukadam and McEwan. This is an open-access article distributed under the terms of the Creative Commons Attribution License (CC $B Y)$. The use, distribution or reproduction in other forums is permitted, provided the original author(s) and the copyright owner(s) are credited and that the original publication in this journal is cited, in accordance with accepted academic practice. No use, distribution or reproduction is permitted which does not comply with these terms. 